\title{
Resource sharing by outer membrane vesicles from a citrus pathogen
}

3 Gabriel G. Araujo ${ }^{1}$, Matheus M. Conforte $^{1}$, Aline D. da Purificação ${ }^{1}$, Iris Todeschini ${ }^{1}$, Edgar E.

4 Llontop $^{2}$, Claudia B. Angeli ${ }^{3}$, Alex Inague ${ }^{2}$, Marcos Y. Yoshinaga $^{2}$, Robson F. de Souza ${ }^{1}$,

5 Rodrigo Papai ${ }^{4}$, Maciel S. Luz ${ }^{4}$, Sayuri Miyamoto ${ }^{2}$, Giuseppe Palmisano ${ }^{3}$, Chuck S. Farah ${ }^{2}$,

6 Cristiane R. Guzzo ${ }^{1 \#}$

$8{ }^{1}$ Department of Microbiology, Institute of Biomedical Sciences, University of São Paulo, Ave.

9 Prof. Lineu Prestes, 1374, Cidade Universitária, 05508-000, São Paulo, SP, Brazil.

$10{ }^{2}$ Department of Biochemistry, Institute of Chemistry, University of São Paulo, Ave. Prof. Lineu

11 Prestes, 748, Cidade Universitária, 05508-000, São Paulo, SP, Brazil.

$12{ }^{3}$ Department of Parasitology, Institute of Biomedical Sciences, University of São Paulo, Ave.

13 Prof. Lineu Prestes, 1374, Cidade Universitária, 05508-900, São Paulo, SP, Brazil.

$14{ }^{4}$ Laboratório de Processos Metalúrgicos, Instituto de Pesquisas Tecnológicas do Estado de São

15 Paulo (IPT), Ave. Prof. Almeida Prado, 532, Cidade Universitária, 05508-901, São Paulo, SP,

16 Brazil.

17 \# To whom correspondence should be addressed: Prof. Cristiane Guzzo Carvalho, Department of

18 Microbiology, Institute of Biomedical Sciences, University of São Paulo, Ave. Prof. Lineu

19 Prestes, 1374, Cidade Universitária, 05508-000, São Paulo, SP, Brazil, phone: +55 113091 -

20 7298; email: crisguzzo@usp.br and crisguzzo@gmail.com.

22 Running title: Resource sharing by OMVs 


\section{Abstract}

25 The causative agent of citrus canker disease, Xanthomonas citri pv. citri, was found to

26 produce copious amounts of outer membrane vesicles (OMVs), frequently forming long

27 membranous tubes under different culture conditions. Lipidomic analysis revealed significant

28 differences in lipid composition between purified vesicles in relation to whole cells. The results

29 suggest an enrichment in saturated cardiolipins and a decrease in unsaturated lipids in the OMV

30 samples, possibly granting them a more rigid structure while allowing their high degree of

31 curvature caused by their small diameters. The vesicles' proteome was found to be significantly

32 enriched in TonB-dependent receptors related to the acquisition of different nutrients. These

33 proteins are known to transport siderophores, which were evidenced to be present in purified $X$.

34 citri OMVs, along with essential metals including iron, zinc, and manganese quantified by

35 elemental analysis. The availability of vesicle-associated nutrients to be incorporated by cells

36 was demonstrated by the use of OMVs as the sole carbon source for bacterial growth. At last, the

37 vesicles also presented esterase and protease activities, which have been associated with

38 virulence in phytopathogens. These evidences point that X. citri cells can use OMVs to share

39 resources within microbial communities, which has potential implications for microbial

40 interactions and plant colonization, affecting their survival and persistence on the host and in the

41 environment.

\section{Importance}

44 The shedding of outer membrane vesicles appears to be universal in Gram-negative

45 bacteria and effectively constitutes a unique secretion pathway for diverse molecules and

46 proteins. To study their possible functions in the citrus pathogen Xanthomonas citri, purified 
47 vesicles from this bacterium were studied by omics and functional approaches. Nutrient

48 transporters were found associated to these structures, which were evidenced to contain

49 siderophores and essential metals. The availability of these nutrients to be incorporated by cells

50 was then demonstrated by showing that purified vesicles can be used as sole carbon sources for

51 microbial growth. Additionally, the samples also presented esterase and protease activities which

52 can contribute to the release of substrates from plant host tissues. These observations help to

53 establish the developing idea of vesicles as shared bacterial resources which can participate in

54 shaping host-associated microbial communities in contrast to other interactions such as bacterial

55 competition.

\section{Introduction}

The production of outer membrane vesicles (OMVs) is known to be extremely common

to Gram-negative bacteria and has been specially explored in pathogens due to their association

60 to virulence factors (Schwechheimer and Kuehn, 2015; Toyofuku et al., 2019). Less commonly

61 described structures are outer membrane tubes, also named tube-shaped membranous structures,

62 nanotubes, nanowires and nanopods in different organisms. The tubes are considered to be a

63 specialized form of OMVs, which assemble in the form of chains or completely fused to one

64 another (Pirbadian et al., 2014; Remis et al., 2014; Pirbadian et al., 2015; Fischer et al., 2019;

65 Toyofuku et al., 2019). These tubes seem to have the potential to bridge cell surfaces at long

66 ranges, but their exact function, if at all dependent on their elongated shape, is still unclear on

67 most cases and varies between different organisms.

68 Myxococcus xanthus outer membrane tubes are some of the most studied of these

69 structures, forming a widespread network between the cells within biofilms that were proposed 
70 to promote coordination for these bacteria's notorious social behaviors by serving as a transport

71 medium for proteins and other molecules (Remis et al., 2014). Nevertheless, simply the presence

72 of the tubes may not be sufficient for such activities since specific factors were found to be

73 necessary to allow effective molecular exchanges through outer membrane connections. Namely,

74 the proteins TraA and TraB were identified by genetic screening to be required for transferring

75 outer membrane proteins by direct contacts between cells, while not affecting the production of

76 tubes (Dey and Wall, 2014; Cao and Wall, 2019). In the zoonotic pathogen Francisella novicida

77 which causes tularemia disease, virulence factors were detected in its OMVs and outer

78 membrane tubes, which interestingly always appear to be of a continuous, non-segmented type.

79 Interaction with host cells led to increased expression of the tubes, suggesting a role of these

80 structures in the infection process (McCaig et al., 2013; Sampath et al., 2018). In Vibrio

81 vulnificus, OMVs carry the virulence factor cytolysin-hemolysin VvhA (Kim et al., 2010), while

82 its segmented tubes seem to exist only transiently as intermediates within the capsule of this

83 opportunistic pathogen (Hampton et al., 2017). Somewhat in contrast to these examples, the

84 outer membrane tubes of Shewanella oneidensis seem play a much clearer role in the biology of

85 this organism. These membranous extensions form "nanowires" from which components of the

86 electron transport chain of this metal-reducing bacterium can reach extracellular mineral electron

87 acceptors (Pirbadian et al., 2014, 2015).

Studies with other environmental bacteria also revealed other possible implications of

89 these structures on cell metabolism. In a marine Flavobacterium sp., OMV chains were proposed

90 to serve as an extension of the cell surface for the degradation and incorporation of substrates

91 (Fischer et al., 2019). OMVs of polycyclic aromatic hydrocarbon-degrading Delftia sp. Cs1-4

92 were found to be contained within tubular "nanopods" surrounded by a surface layer protein, 
$93 \mathrm{NpdA}$, the production of which was stimulated by growth on phenanthrene. The presence of

$94 \mathrm{NpdA}$ and the formation of an encasing structure for OMV tubes seem to be a characteristic

95 distributed within the Comamonadaceae family (Shetty et al., 2011).

96 The examples presented above represent some of the exploration done on the relatively

97 few, but nonetheless diverse bacteria identified that assemble extracellular tubular-shaped

98 structures from their outer membrane. Nevertheless, OMVs are most commonly found not as

99 chains but as free entities, which are produced by Gram-negative bacteria in different

100 environments, such as biofilms, planktonic cultures, and within hosts (Hellman et al., 2000;

101 Biller et al., 2014; Hickey et al., 2015). More generally speaking, extracellular membrane

102 vesicles are also commonly produced by Gram-positive bacteria, archaea, and by eukaryotic cells

103 (Schwechheimer and Kuehn, 2015).

104 Due to them being an effective way for microbial cells to release the most diverse

105 compounds, OMV production can be used as a secretion mechanism and thus have been called

106 the "type zero secretion system" (Schwechheimer and Kuehn, 2015; Guerrero-Mandujano et al.,

107 2017; Toyofuku et al., 2019). Differently from other bacterial secretion systems, OMVs require a

108 remodeling of the Gram-negative envelope to release vesicles made of outer membrane

109 constituents with a periplasmic lumen. Therefore, different bacterial envelope crosslinks and

110 non-covalent interactions between proteins located in the membrane that interact with the cell

111 wall must be broken during the secretion of OMVs (Schwechheimer and Kuehn, 2015). Details

112 of this process are still unclear, as well as if there is any generalized protein system actively

113 involved in OMV biogenesis. Another process that is still not well understood is cargo selection,

114 if proteins and chemical compounds can be directed into OMVs by the cell and secreted to the

115 extracellular medium (Lappann et al., 2013; Elhenawy et al., 2014). In some bacteria, OMV 
116 synthesis can be triggered under stress conditions, such as antibiotic treatments that activate SOS

117 response and under oxidative stress (McBroom and Kuehn, 2007; Maredia et al., 2012;

118 Macdonald and Kuehn, 2013; Schwechheimer and Kuehn, 2013). Under these situations, OMVs

119 may serve as a way to remove potentially harmful compounds, such as misfolded proteins.

121 in bacterial communities and during host colonization (Evans et al., 2012; Toledo et al., 2012;

122 Biller et al., 2014; Schwechheimer and Kuehn, 2015). The role of OMVs in nutrition has been

123 suggested for different bacteria, such as M. xanthus, the cyanobacterium Prochlorococcus sp.,

124 Borrelia burgdorferi, Neisseria meningitidis, Porphyromonas gingivalis, Moraxella catarrhalis,

125 and for cytoplasmic membrane vesicles of Mycobacterium tuberculosis (Aebi et al., 1996; Evans

126 et al., 2012; Toledo et al., 2012; Lappann et al., 2013; Biller et al., 2014). It is not clear if OMVs

127 have a universal role for nutrient acquisition, but in some cases they have been suggested to act

128 as public goods that benefit the producer cells as well as other bacteria from the community that

129 can absorb them or use the products released by the action of enzymes located in the OMVs

130 (Evans et al., 2012; Elhenawy et al., 2014; Schwechheimer and Kuehn, 2015). An example is the

131 relationship between bacteria found in the gut microbiota. OMVs produced by Bacteroides

132 species carry hydrolases and polysaccharide lyases which can be used by bacteria that do not

133 produce these enzymes to metabolize polysaccharides as nutrient sources in a mutualistic

134 interaction (Rakoff-Nahoum et al., 2014).

135 Few studies have focused in the OMVs of phytopathogens. Still, research on this topic

136 has revealed that, similarly to their animal-colonizing counterparts, bacteria that inflict diseases

137 on plants were found to produce vesicles loaded with virulence-associated proteins and are

138 capable of inducing immune responses on their hosts (Sidhu et al., 2008; Solé et al., 2015; Bahar 
139 et al., 2016; Nascimento et al., 2016; Katsir and Bahar, 2017; Feitosa-Junior et al., 2019). These

140 observations include Xanthomonas species and the closely related plant pathogen Xylella

141 fastidiosa.

142 Strains from the genus Xanthomonas, known to cause diseases in a number of plant hosts,

143 frequently contain most of the traditional bacterial macromolecular secretion systems named

144 type I to VI (Büttner and Bonas, 2010; Alvarez-Martinez et al., 2021). OMVs, however, are

145 comparatively much less studied than these other systems in these bacteria. Thus, this work

146 focuses on unveiling the composition and possible roles of vesicles from one such

147 phytopathogen, the causative agent of citrus canker disease, Xanthomonas citri pv. citri strain

148306 (X. citri). Long extracellular appendages composed of OMVs were identified under different

149 culture conditions, and the purified OMVs were investigated by elemental analysis, proteomic

150 and lipidomic techniques, as well as by functional approaches. The vesicles were found to be

151 potential vehicles of nutrients and essential ions available for incorporation by bacterial cells.

152 This function, in association with the esterase and protease activities observed in the purified $X$.

153 citri OMVs, may possibly aid in the microbial colonization of the plant host and contribute to

154 disease establishment.

156 Results and Discussion

Visualization of $\mathrm{X}$. citri outer membrane vesicles and tubes by negative stain TEM

Negative stain transmission electron microscopy (TEM) revealed the presence of tubular

159 extensions from $X$. citri cells grown in plates of different culture media, identified as outer

160 membrane tubes (Fig. 1). Upon closer inspection, the tubes were found to be formed from

161 vesicle chains, occasionally with a well-defined segmentation but frequently presenting nearly 
162 indistinguishable boundaries between links, seeming almost continuous. The size of the tubes

163 ranged from short segments up to a few micrometers in length. Surrounding the cells in all

164 conditions tested, a multitude of outer membrane vesicles (OMVs) was also present (Fig. 1). For

165 most of their extension, the tubes appear to be composed of vesicles with a more homogeneous

166 diameter $(58-74 \mathrm{~nm})$ than the isolated OMVs. Each tube seem to possess larger vesicles at its tips

167 (88-103 nm), and some longer tubes appear to be formed by segments connected by these larger

168 subunits.

Amongst the different culture media tested, Silva-Buddenhagen (SB) plates (Ou, 1985)

170 seemingly produced the largest amount of tubes and vesicles, and thus were used for further

171 experiments. The agar percentage $(0.6-1.5 \%)$ seemed to not significantly affect the production

172 of tubes, but these structures seemed to be rarer when the cells were grown in liquid medium

173 (Fig. S1).

Purification of outer membrane vesicles combined with lipidomics and proteomics

175 analyses

176 Pure, cell-free, OMVs could be purified from cultures grown in SB plates by filtration

177 and density gradient centrifugation generating a clear yellow suspension (Fig. 2A). The tubes did

178 not appear in the final preparations, being either lost during the process or disassembling from

179 the manipulation (Fig. 2B). The purity of the OMV preparations was confirmed by negative stain

180 TEM and absence of growth from contaminating cells. In addition to that, dynamic light

181 scattering (DLS) was employed to measure their diameter distribution. The vesicles were

182 determined to be monodispersed, with sizes ranging from about 40 to $150 \mathrm{~nm}$, with a peak at

183 around $75 \mathrm{~nm}$ (Fig. 2C), well within previous descriptions for OMVs (Schwechheimer and 
184 Kuehn, 2015). The purified samples were then subjected to different analytical procedures to

185 reveal their molecular composition.

187 pure OMVs, partially purified OMV preparations ("OMV-enriched" samples, in which the cells

188 were removed by filtration but not submitted to the density gradient centrifugation step), and

189 whole $X$. citri cells revealed substantial differences between the samples. Sixty-six different

190 lipids were identified, divided into 6 subclasses: cardiolipins (CL), free fatty acids (FFA),

191 phosphatidylcholine (PC), phosphatidylethanolamine (PE), phosphatidylglycerol (PG), and

192 methylated-phosphatidylserine (PS-Me) (Fig. 3A). CL, a type of diphosphatidylglycerol lipid,

193 was the most diverse and abundant lipid subclass in all samples (Fig. 3B). The main difference

194 observed was that, in relation to whole cells, pure OMVs appeared to be enriched in CL and 195 relatively impoverished in PG (the biosynthetic precursor of CL). Free fatty acids were highly 196 prevalent, likely reflecting their important role as common metabolic intermediates. It is 197 important to note that the main components of the outer leaflet of bacterial outer membranes, 198 lipopolysaccharides (LPS), were not evaluated in this analysis due to their relatively hydrophilic 199 nature, making them too polar to be extracted along the other lipids.

200 A volcano plot analysis revealed 20 altered lipids between OMV-containing and whole 201 cell samples, all presenting significant ( $\mathrm{p}<0.05$; FDR-adjusted $t$-test) fold changes values above 2021.5 (Fig. S2). In the heatmap distribution for these altered lipids, according to one-way ANOVA, 203 each sample type clustered with its replicates, with the OMVs (partially or completely purified) 204 grouping separately from whole cells (Fig. 3C). Interestingly, it could be observed that the 205 OMVs had relatively increased amounts of several CL species linked to saturated fatty acids and 
206 decreased quantities of phospholipids (including CL) linked to unsaturated fatty acids when

207 compared to the whole cells.

208 The cone-shaped lipid CL is known to localize to negative curvature regions on

209 membranes (Renner and Weibel, 2011; Beltran-Heredia et al., 2019), such as in the inner leaflet

210 of $X$. citri OMVs, which present small diameters and are thus highly curved structures.

211 Additionally, the relatively higher saturation of the CL-linked chains in the vesicles may grant

212 the OMVs with more membrane rigidity (Tashiro et al., 2011). CL has been described as

213 organizing into microdomains where CL-interacting proteins localize (Sorice et al., 2009;

214 Planas-Iglesias et al., 2015; Lin and Weibel, 2016). In this manner, protein affinity for these

215 lipids could contribute cargo sorting into X. citri OMVs.

216 Nanoflow liquid chromatography-tandem mass spectrometry (nLC-MS/MS) was used for

217 the proteomic analysis of two replicates of purified OMV suspensions using in-solution

218 digestion. Parallel to that, four bands of OMV proteins separated in a SDS-PAGE gel were used

219 for a gel electrophoresis liquid chromatography (GeLC) approach using in-gel digestion (Fig.

220 4A). The data from the gel band samples were pooled and quantitatively compared to the two

221 replicates of the in-solution digestion. A total of 698 proteins were identified with at least one

222 peptide, with 561 proteins presenting two or more peptides (Data Set S1 and Data Set S2).

223 Using their iBAQ (intensity based absolute quantification) values, the top 100 most abundant

224 proteins from each sample were selected and compared (Fig. 4B). While the in-solution

225 duplicates presented a large overlap, sharing 86 of their top 100 proteins, the GeLC approach

226 (gel bands samples) revealed the most distinct profile, with 49 of their most abundant proteins

227 being unique to its set. 
The grouping of the top 100 non-redundant proteins with the highest iBAQ values for

229

230

231

232

233

234

235

236

237

238

239

240

241

242

243

244

245 each sample yielded a list of 163 different proteins (Table S1). Subcellular localization prediction with PSORTb, manually curated based on sequence annotations, pointed out that $42.3 \%$ of these sequences are expected to be outer membrane proteins and $12.3 \%$ are likely periplasmic (Fig. 5A). The presence of inner membrane and cytoplasmic components observed in the proteome of $X$. citri OMVs, including ribosomal proteins, is commonly reported in the literature but remains unexplained as to how these proteins might associate to OMVs (Schwechheimer and Kuehn, 2015; Sjöström et al., 2015; Toyofuku et al., 2019; Zwarycz et al., 2020). Additionally, a cellular location could not be predicted for $21.5 \%$ of the identified proteins. For a different view on protein localization, SignalP was used to predict the secretion mechanisms of the OMV proteins (Fig. 5B). Nearly half of them (49.7\%) contained signal peptides and almost one-fifth (19\%) were predicted lipoproteins. A large "other" category (29.4\%) includes cytoplasmic components and other proteins with non-classical or unknown secretion mechanisms.

From a functional perspective, proteins containing a TonB-dependent receptor domain were the most significantly enriched in the vesicles in comparison to the X. citri pv. citri 306 genome (Fig. 5C), as determined for Pfam annotations by the statistical enrichment analysis function of the STRING database (Franceschini et al., 2013). In accordance with that, the STRING analysis also identified a number of InterPro domains related to TonB-dependent receptors as the most significantly enriched in the samples (Fig. S3). In total, of the 163 most abundant proteins (Table S1), 31 were found to contain a "TonB-dependent receptor" Pfam domain (PF00593), the same set which contained a "TonB-dependent receptor-like, beta-barrel" InterPro domain (IPR000531). In a previous report, TonB-dependent receptors were found to 
252 campestris pv. campestris (Sidhu et al., 2008). These outer membrane receptors are known to

253 transport a range of nutrients, including metal-binding compounds (particularly siderophores),

254 nickel complexes, vitamin $\mathrm{B}_{12}$, and carbohydrates (Blanvillain et al., 2007; Krewulak and Vogel,

255 2011). Based on sequence annotations, the OMV proteome presents different types of TonB-

256 dependent receptors which may bind diverse substrates (Table S1). These proteins are expected

257 to remain able to bind to their specific ligands in the surface of the OMVs, though their

258 internalization should not occur under these conditions since inner membrane components of this

259 transport system are necessary to power substrate translocation (Krewulak and Vogel, 2011).

Based on similar observations in relation to ion transporters in their proteomes, OMVs

262 from different bacterial species have been suggested to be involved in metal acquisition

263 (Schwechheimer and Kuehn, 2015). Given this abundance of TonB-dependent receptors in the $X$.

264 citri OMVs, mainly associated with siderophore transport, chrome azurol S (CAS) agar plates

265 (Schwyn and Neilands, 1987) were used as a qualitative assay to evidence the presence of this

266 type of molecule associated with the purified vesicles. OMV suspensions added to the medium

267 caused its discoloration, indicating the displacement of the iron in the blue-colored CAS complex

268 by the putative high affinity siderophores present in the samples (Fig. 6A). It is interesting to

269 note that the iron-scavenging role of siderophores for microbial growth can also be important in

270 phytopathogens for interactions with the host plant, promoting virulence and potentially

271 triggering immune responses (Aznar and Dellagi, 2015).

To further investigate the association of the OMVs with essential metals, their elemental

273 composition was determined by triple quadrupole inductively coupled plasma-mass spectrometry 
274 (TQ ICP-MS) (Fig. 6B). Table S2 presents the full results for all tested elements (C, Mg, S, Ca,

$275 \mathrm{Mn}, \mathrm{Fe}, \mathrm{Co}, \mathrm{Ni}, \mathrm{Cu}, \mathrm{Zn}, \mathrm{Br}, \mathrm{Se}, \mathrm{I}$, and $\mathrm{Ba})$. The relative concentration of the elements in relation

276 to carbon, reported as element-to-carbon ratios, was used as a comparative abundance value of

277 the chemical elements in OMVs. The analysis confirmed the presence iron in the OMVs

$278(899 \pm 450 \mathrm{ppb}$ in relation to carbon), concurrent with the observed occurrence of receptors for

279 iron-binding molecules in the vesicles and evidence for the presence of siderophores in the

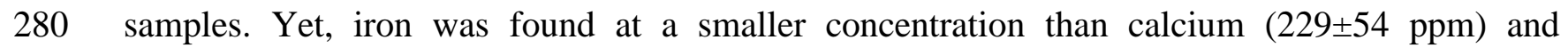

281 magnesium $(58 \pm 5 \mathrm{ppm})$, which are probably mostly bound to the LPS layer on the vesicles'

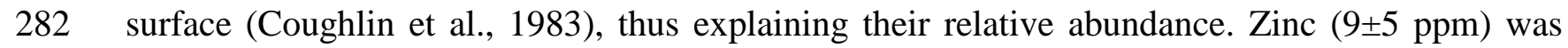

283 another biologically important metal ion determined at substantial levels in the OMVs. It can be

284 used as a cofactor for different enzymes, including for metallopeptidases known to contribute to

285 the pathogenicity of some organisms (Hase and Finkelstein, 1993). In fact, a few such zinc-

286 dependent metallopeptidases were identified in the OMVs (Data Set S1 and Data Set S2),

287 though their specific biological roles have not yet been defined. In addition to that, manganese

288 (450 $\pm 45 \mathrm{ppb})$ can also act as a cofactor in a number of different enzymes and was also quantified

289 in the samples. At last, cobalt $(12 \pm 5 \mathrm{ppb})$ was detected in the vesicles. This is interesting given

290 that among the TonB-dependent receptors enriched in the OMVs (Table S1), at least one is

291 annotated as specific for vitamin $\mathrm{B}_{12}$, a molecule which contains a coordinated cobalt ion. This

292 protein, XAC3194, specifically contains a "TonB-dependent vitamin B $_{12}$ transporter BtuB"

293 InterPro Domain (IPR010101).

294 To test if the vesicles and the material associated to them are accessible to X. citri cells

295 and can be utilized by them as nutrient sources, purified OMVs were tested as the sole carbon

296 source for microbial growth. Substantial growth was observed for the samples where OMVs 
were added, with the highest vesicle protein concentration tested leading to a multiplication of

298 about 1000-fold in colony-forming units (Fig. 6C), indicating that the macromolecules

299 associated with the vesicles were being consumed by the bacteria. This confirms the ability of

300 these structures and the material they carry to be incorporated and used by cells, strengthening

301 the hypothesis that they can act as nutrient vehicles such as has been proposed for other bacteria

302 (Aebi et al., 1996; Evans et al., 2012; Toledo et al., 2012; Lappann et al., 2013; Biller et al.,

303 2014; Schwechheimer and Kuehn, 2015). The mechanism for this incorporation, however,

304 remains unclear. It could be mediated by the degradation of the vesicles for the release of their

305 contents in some manner, but fusion of the OMVs to the cells' surfaces can also possibly be

306 considered (Evans et al., 2012).

\section{Esterase and protease activity of OMVs}

Additional functional assays with the purified $X$. citri OMVs revealed they present esterase activity. Qualitative assays on agar plates evidenced their capacity to cause the

310 hydrolysis of the triglyceride tributyrin emulsified in the medium, generating a clear halo (Fig.

311 7A), as well as to release the fatty acids from molecules of Tween 20, leading to their

312 precipitation with the calcium added to the plates (Fig. 7B). Further assays were performed in

313 suspension with $p$-nitrophenyl butyrate ( $p$ NP-C4) and $p$-nitrophenyl octanoate $(p$ NP-C8) as

314 chromogenic substrates, adding controlled amounts of vesicles quantified by their protein

315 content. Using $p$ NP-C4, a clear trend could be observed of increasing OMV protein

316 concentration leading to faster product release (Fig. 7C). The longer chain substrate $p$ NP-C8 was

317 also hydrolyzed, but there were no clear differences between the different quantities of added

318 vesicles (Fig. 7D). This is probably due to the low solubility of $p$ NP-C8 in the medium, thus

319 becoming the limiting factor for the reaction. Nonetheless, with both $p$-nitrophenyl esters, a 
320 plateau seems to have been reached during the incubation with the OMVs, suggesting all the

321 available substrate was consumed.

322 The esterase activity associated with the OMVs measured for a broad range of substrates

323 can possibly be attributed to the outer membrane esterase with an autotransporter domain

324 XAC3300 (gene name estA) identified among the most abundant proteins in the proteome,

325 though other undetected enzymes may be present. Esterases have been reported to contribute to

326 the virulence of phytopathogens, playing roles such as aiding in the degradation of cutin, pectin,

327 or xylan in plant host tissues (Fett et al., 1992; Aparna et al., 2009; Tamir-Ariel et al., 2012;

328 Dejean et al., 2013; Nascimento et al., 2016; Tayi et al., 2016; Ueda et al., 2018), depending on

329 their substrate preference. In Xanthomonas oryzae pv. oryzae, loss of function of the LipA

330 esterase lead to loss of virulence on rice and to the inability to induce host defense responses

331 (Aparna et al., 2009), while a LipA mutant of Xanthomonas campestris pv. vesicatoria induced

332 less severe symptoms on tomato than the wild type (Tamir-Ariel et al., 2012). The LipA ortholog

333 of the related plant pathogen Xylella fastidiosa, LesA, was found to be present in OMVs. This

334 esterase was able to induce hypersensitive response-like symptoms in grapevine leafs, while a

335 LesA mutant showed decreased virulence (Nascimento et al., 2016). At last, a LipA mutant of $X$.

336 citri presented reduced symptoms when inoculated into citrus leaves (Assis et al., 2017). This

337 particular protein (XAC0501), however, could not be identified in the $X$. citri OMV proteome

338 (Data Set S1 and Data Set S2) but other esterases could perform similar functions in the plant

339 host.

340 Proteases are another class of hydrolases that have been associated to pathogenesis in

341 plant-infecting microorganisms (Hou et al., 2018; Figaj et al., 2019). In the X. citri OMV

342 samples, this enzymatic activity was identified utilizing a fluorescent casein substrate (Fig. 8), 
343 revealing yet another function connected to these structures. More substrate degradation was

344 observed with the addition of increasing amounts of OMVs to the reactions, while a commercial

345 EDTA-free protease inhibitor mix was able to substantially reduce activity (Fig. 8). In $X$.

346 campestris pv. campestris, a protease-deficient mutant presented a substantial loss of

347 pathogenicity in turnip leaves (Dow et al., 1990), whereas the XCV3671 protease of X.

348 campestris pv. vesicatoria was determined to contribute to virulence in pepper plants and

349 evidenced to be secreted in association with OMVs from this strain (Solé et al., 2015). Further

350 research could show if similar enzymes, both proteases and other esterases, are important for $X$.

351 citri infection and citrus canker development.

352 Considering the identified enzymatic activities associated with the $X$. citri OMVs, as well

353 as the presence of other hydrolases detected by proteomic analyses (Table S1), the vesicles may

354 be an important resource in plant colonization and pathogenesis. The release of products from

355 the degradation of macromolecules can be another manner in which the vesicles would be related

356 to nutrient acquisition, acting as public goods for other $X$. citri cells and possibly the microbial

357 community in general. These processes can facilitate the bacterial colonization of plant tissues

358 and thus participate in disease development.

\section{Conclusion}

361 X. citri cells express outer membrane tubes and vesicles carrying proteins, molecules, and

362 ions that may benefit bacterial cells. The OMV lipid profile revealed their higher content of

363 saturated cardiolipins with a relative impoverishment in unsaturated lipids. This might grant

364 them more rigidity while maintaining the small diameter of the vesicles. The proteome of the

365 vesicles revealed an abundance of transporters related to the uptake of nutrient molecules from 
the medium. This includes receptors for siderophores, which were also potentially detected in the

367 samples as well as different biologically important metals. Based on these observations, our

368 hypothesis that the OMVs from $X$. citri can be used for sharing resources in microbial

369 communities is also supported by the observation that the vesicles' contents can be assimilated

370 and used for microbial growth. At last, another potential resource packaged with the OMVs is

371 their esterase and protease activities, which can release nutrients from the plant host tissue and

372 help to promote microbial colonization, potentially facilitating infection.

This work further establishes the association of OMVs with the acquisition and sharing of

374 nutrient molecules and ions in microbial communities. Microbial interactions can be important

375 driving forces shaping community structure in oligotrophic habitats such as leaf surfaces

376 (Schlechter et al., 2019). The balance between this apparently cooperative behavior with

377 Xanthomonas' notorious competitive proclivities conferred by its bactericidal type IV secretion

378 system (Sgro et al., 2019) may be especially significant for co-occurring epiphytic bacteria and

379 their own particular interactions with the plant (Hassani et al., 2018). Further research on this

380 possible indirect modulation of host physiology could reveal unexplored processes emerging

381 from a pathogen aptly manipulating microbial interaction networks with its diverse suite of

382 secretions systems.

384 Materials and Methods

\section{Bacterial cultures and growth conditions}

For all experiments, Xanthomonas citri pv. citri strain 306 (X. citri) was first grown in

387 liquid LB medium (tryptone, $10 \mathrm{~g} \mathrm{l}^{-1}$; yeast extract, $5 \mathrm{~g} \mathrm{l}^{-1} ; \mathrm{NaCl}, 10 \mathrm{~g} \mathrm{l}^{-1}$ ) at $30{ }^{\circ} \mathrm{C}$ to $\mathrm{OD} 0.3$ at

$388600 \mathrm{~nm}$. The cultures were then inoculated on different solid culture media and incubated at 30 
${ }^{\circ} \mathrm{C}$ for 3 days. SB medium (yeast extract, $5 \mathrm{~g} \mathrm{l}^{-1}$; peptone, $5 \mathrm{~g} \mathrm{l}^{-1}$; glutamic acid, $1 \mathrm{~g} \mathrm{l}^{-1}$; sucrose, 5

$\left.\mathrm{g}^{-1} ; \mathrm{pH} 7\right)$ with $1.5 \%$ of agar $(\mathrm{w} / \mathrm{v})(\mathrm{Ou}, 1985)$, was used for the production and purification of

391 OMVs.

\section{Purification of $O M V s$}

$X$. citri colonies grown on SB plates at $30{ }^{\circ} \mathrm{C}$ for 3 days were scraped from the agar

394 surfaces and suspended in phosphate buffered saline, $\mathrm{PBS}\left(\mathrm{NaCl}, 8 \mathrm{~g} \mathrm{l}^{-1} ; \mathrm{KCl}, 0.2 \mathrm{~g}^{-1}\right.$;

$395 \mathrm{Na}_{2} \mathrm{HPO}_{4}, 1.44 \mathrm{~g} \mathrm{l}^{-1} ; \mathrm{KH}_{2} \mathrm{PO}_{4}, 0.24 \mathrm{~g} \mathrm{l}^{-1}$ ). After homogenization of the suspension, cells were

396 precipitated by multiple centrifugations steps $\left(10,000-30,000 \times \mathrm{g}\right.$ at $4{ }^{\circ} \mathrm{C}$, Beckman Avanti J-

397 30I) until the supernatant appeared clean. Then, the samples were ultracentrifuged at $100,000 \times \mathrm{g}$

398 at $4{ }^{\circ} \mathrm{C}$ for at least 2 hours to pelletize the OMVs. The pellets were resuspended in a small

399 volume of PBS and filtered through a $0.22 \mu \mathrm{m}$ syringe filter to remove remaining cells inside a

400 laminar flow hood. The samples were aseptically manipulated from this step on. The filtered

401 OMVs were further purified by being loaded at the bottom of a filtered OptiPrep (Sigma) density

402 gradient (35 to $0 \%$ in PBS) and ultracentrifuged at $200,000 \times \mathrm{g}$ for at least 12 hours at $4{ }^{\circ} \mathrm{C}$

403 (Beckman Optima XL-100K). The corresponding clear yellow band was collected, diluted in

404 PBS, and pelletized again at $100,000 \times \mathrm{g}$ for 2 hours to wash out the density gradient medium.

405 Absence of contamination was determined by lack of growth on LB plates incubated at $30{ }^{\circ} \mathrm{C}$.

406 DLS (Malvern Zetasizer) was used to characterize the size of the recovered OMVs. Total

407 proteins in purified samples were quantified by a Qubit 3.0 fluorometer (Thermo Scientific).

\section{Sodium dodecyl sulfate-polyacrylamide gel electrophoresis (SDS-PAGE)}

409 Purified OMV samples were added with SDS-PAGE reducing sample buffer and treated

410 at $90{ }^{\circ} \mathrm{C}$ for 10 minutes. Proteins were separated in $15 \%$ Tris-Glycine SDS-PAGE gels and

411 stained with Coomassie Brilliant Blue. 


\section{Negative stain transmission electron microscopy (TEM)}

Samples were applied to glow-discharged carbon film-coated copper grids (400 Mesh,

414 CF400-Cu, Electron Microscopy Sciences), washed with Milli-Q ultrapure water, and negatively

415 stained with uranyl acetate $2 \%(w / v)$, blotting on filter paper after each step. A FEI Tecnai G20

$416200 \mathrm{kV}$ TEM (Department of Cell and Developmental Biology, Institute of Biomedical Sciences,

417 University of São Paulo) or a JEOL JEM 2100200 kV TEM (Institute of Chemistry, University

418 of São Paulo) were used for image acquisition.

\section{Liquid chromatography-tandem mass spectrometry lipidomics}

Lipids were extracted by the Bligh and Dyer method (Bligh and Dyer, 1959), using

421 ethanol-washed glass tubes and glass Pasteur pipettes for all steps. $100 \mu 1$ of the samples were

422 added to $400 \mu \mathrm{l}$ of PBS (50 mM) containing $100 \mu \mathrm{M}$ of deferoxamine. In the same tubes, $200 \mu \mathrm{l}$

423 of a mix of internal standards (Avanti Polar Lipids and Sigma) and $300 \mu$ of butylated

424 hydroxytoluene (BHT) in methanol were added. The samples were then mixed with

425 chloroform/ethyl acetate solution (4:1) and vortexed for 1 minute. Next, the tubes were

426 centrifuged at $1,500 \times \mathrm{g}$ for 2 minutes at $4{ }^{\circ} \mathrm{C}$ and the organic phase at the bottom was collected

427 and transferred to a clean vial. The solvent was dried under a flow of $\mathrm{N}_{2}$ and the lipids were

428 resuspended in $100 \mu \mathrm{l}$ of isopropyl alcohol. The samples were stored at $-80{ }^{\circ} \mathrm{C}$ before being

429 analyzed by a previously established untargeted lipidomic method (Chaves-Filho et al., 2019).

Sample preparation for proteomics analysis

For in-solution digestion, OMV samples were boiled for 10 minutes before the proteins

432 were precipitated with ethanol/acetone, and dissolved in urea $8 \mathrm{M}$ in $\mathrm{NH}_{4} \mathrm{HCO}_{3} 100 \mathrm{mM}$.

433 Dithiothreitol (DTT) was added to a final concentration of $10 \mathrm{mM}$, and the samples were

434 incubated for $30 \mathrm{~min}$ at $37^{\circ} \mathrm{C}$. The samples were cooled down, iodoacetamide was added to a 
435 final concentration of $40 \mathrm{mM}$, and the samples were then incubated for $30 \mathrm{~min}$ at room

436 temperature in the dark. DTT was added again, followed by digestion buffer $\left(\mathrm{NH}_{4} \mathrm{HCO}_{3} 50 \mathrm{mM}\right.$

437 in a solution of $10 \%$ acetonitrile $-\mathrm{ACN}$ ) to dilute ten times the urea concentration. Trypsin was

438 added to digestion buffer for a final trypsin to protein ratio of 1:50, and the solution was

439 incubated overnight at $37^{\circ} \mathrm{C}$. The digestion was stopped by the addition of formic acid (FA).

440 For in-gel digestion (GeLC approach), the gel bands were completely destained, treated

441 with $10 \mathrm{mM}$ DTT at $56^{\circ} \mathrm{C}$ for $45 \mathrm{~min}, 55 \mathrm{mM}$ IAA at room temperature for $30 \mathrm{~min}$ in the dark

442 and digested at $37{ }^{\circ} \mathrm{C}$ for $16 \mathrm{hrs}$ with $2 \mu \mathrm{g}$ sequencing grade modified trypsin, Porcine

443 (Promega). The resultant peptides were extracted in 40\% ACN/0.1\% TFA into fresh Protein

444 LoBind ${ }^{\circledR}$ microtubes, dried down by vacuum centrifugation, and resuspended in $50 \mu \mathrm{L} 0.1 \%$

445 TFA. Peptide samples obtained from the in-solution and in-gel digestions were desalted using

446 C18 disks packed in a p200 pipette tip. Peptides were eluted with 50\% ACN and dried down.

\section{Nano-flow liquid chromatography-tandem mass spectrometry-based proteomics}

Tryptic peptides were resuspended in $0.1 \%$ FA and analyzed using an EASY-nLC system

449 (Thermo Scientific) coupled to LTQ-Orbitrap Velos mass spectrometer (Thermo Scientific) at

450 the Core Facility for Scientific Research at the University of São Paulo (CEFAP-

451 USP/BIOMASS). The peptides were loaded onto a C18 PicoFrit column (C18 PepMap, $75 \mu \mathrm{m}$

$452 \mathrm{id} \times 10 \mathrm{~cm}, 3.5 \mu \mathrm{m}$ particle size, $100 \AA$ pore size; New Objective, Ringoes, NJ, USA) and 453 separated with a gradient from $100 \%$ mobile phase A (0.1\% FA) to $34 \%$ phase B $(0.1 \%$ FA, $95 \%$

$454 \mathrm{ACN}$ ) during $60 \mathrm{~min}, 34 \%-95 \%$ in $15 \mathrm{~min}$, and $5 \mathrm{~min}$ at $95 \%$ phase $\mathrm{B}$ at a constant flow rate of

$455250 \mathrm{~nL} / \mathrm{min}$. The LTQ-Orbitrap Velos was operated in positive ion mode with data-dependent

456 acquisition. The full scan was obtained in the Orbitrap with an automatic gain control target

457 value of $10^{6}$ ions and a maximum fill time of $500 \mathrm{~ms}$. Each precursor ion scan was acquired at a 
resolution of 60,000 FWHM in the 400-1500 m/z mass range. Peptide ions were fragmented by

459 CID MS/MS using a normalized collision energy of 35\%. The 20 most abundant peptide were

460 selected for MS/MS and dynamically excluded for a duration of 30s. All raw data were accessed

461 in the Xcalibur software (Thermo Scientific).

\section{$\underline{\text { Proteomics data analysis }}$}

Raw data were processed with MaxQuant (Tyanova et al., 2016) using Andromeda search

engine against the SwissProt Xanthomonas axonopodis pv. citri (strain 306) database (4354

entries downloaded from UniProt.org, Jan/2021) with common contaminants for protein

466 identification. Database searches were performed with the following parameters: precursor mass

467 tolerance of $10 \mathrm{ppm}$, product ion mass tolerance of $0.6 \mathrm{Da}$; trypsin cleavage with two missed

468 cleavage allowed; carbamidomethylation of cysteine (57.021 Da) was set as a fixed modification,

469 and oxidation of methionine (15.994 Da) and protein N-terminal acetylation (42.010 Da) were

470 selected as variable modifications. All identifications were filtered to achieve a protein peptide

471 and PSMs, false discovery rate (FDR) of less than $1 \%$, and a minimum of one unique peptide

472 was required for protein identification. Protein quantification was based on the MaxQuant label-

473 free algorithm using both unique and razor peptides for protein quantification. Protein abundance

474 was assessed on label-free protein quantification (LFQ) based on extracted ion chromatogram

475 area of the precursor ions activating the matching between run features. Intensity based absolute

476 quantification (iBAQ) values were used to calculate the relative protein abundance within

477 samples. MS data have been submitted to the PRIDE repository, project accession: PXD025405,

478 username: reviewer_pxd025405@ebi.ac.uk, password: MyMyVfmr.

479 Statistical enrichment analyses of Pfam and InterPro domains and FDR calculations were

480 obtained from the STRING database (Franceschini et al., 2013). PSORTb 3.0 was used for 
481 subcellular localization prediction of the identified proteins (Yu et al., 2010), followed by

482 manual curation based on sequence annotations, and SignalP 5.0 was used for predicting protein

483 secretion mechanisms (Armenteros et al., 2019).

Elemental analysis by Triple Quadrupole Inductively Coupled Plasma-Mass

Triple Quadrupole Inductively Coupled Plasma-Mass Spectrometry (iCAP TQ ICP-MS,

Thermo Fisher Scientific, Bremen, Germany) equipped with a Micro Mist nebulizer (400 $\mu \mathrm{L}$ $\min ^{-1}$ ) combined with a cyclonic spray chamber (both obtained from ESI Elemental Service \&

489 Instruments GmbH, Mainz, Germany) and an auto-sampler ASX-560 (Teledyne CETAC

490 Technologies, Omaha, NE, USA) was used to perform quantitative analysis of the elements in

491 OMVs samples. The instrument was tuned prior to the elemental analysis to obtain the highest

492 sensitivity. The interface was assembled using a nickel sample cone and a nickel skimmer cone 493 with an insert version for high matrix $(3.5 \mathrm{~mm})$.

The TQ ICP-MS was operated with 99.999\% Argon (Air Products). Helium and oxygen

$501 \mathrm{Cu}, \mathrm{Zn}$, and Ba solutions (PlasmaCAL, SCP Science containing $1000 \mathrm{mg} \mathrm{l}^{-1}$ each) were used to 502 calibrate these elements. Mg (1000 mg l-1, CertiPUR, Merck), Se (1000 mg l'-1, Wako Pure 503 Chemical Industries), oxalate standard for carbon quantification (10000 mg $\mathrm{l}^{-1}$, TraceCERT, 

Bromine and Sulfur quantification (10 $\mathrm{mg} \mathrm{l}^{-1}$, TraceCERT, Sigma-Aldrich) were also used to calibrate these respectively elements. The OMV samples were diluted to $500 \mu 1$ with PBS buffer prior to TQ ICP-MS analysis and PBS was used as a method blank. Table $\mathbf{S 4}$ displays the main analytical performance characteristics achieved: linear range, sensitivity, limit of detection (LOD), and coefficient of determination.

511 relative standard deviation of less than $3 \%$ for all analytes) and the accuracy was checked by

512 spike and recovery tests at four different levels of concentration, obtaining acceptable values 513 ranging from 93 to $105 \%$.

\section{Siderophore detection and bacterial growth assays}

517 growth using purified OMVs as sole carbon sources was assayed in M9 minimal medium

518 without glucose $\left(\mathrm{Na}_{2} \mathrm{HPO}_{4}, 6.8 \mathrm{~g} \mathrm{l}^{-1} ; \mathrm{KH}_{2} \mathrm{PO}_{4}, 3 \mathrm{~g} \mathrm{l}^{-1} ; \mathrm{NH}_{4} \mathrm{Cl}, 1 \mathrm{~g} \mathrm{l}{ }^{-1} ; \mathrm{NaCl}, 0.5 \mathrm{~g} \mathrm{l}\right.$; $\mathrm{MgSO}_{4}, 2$

$\left.519 \mathrm{mM} ; \mathrm{CaCl}_{2}, 2 \mathrm{mM}\right)$. About $10^{3}$ stationary phase cells $\mathrm{l}^{-1}$, equivalent to around 10 colony forming

520 units (CFU) for each $10 \mu \mathrm{l}$ droplet plated, were used as the initial population for the experiments.

521 To the samples, 0,125 , or $375 \mu \mathrm{g} \mathrm{ml}^{-1}$ of total OMV proteins were added, and the tubes were 522 incubated at $30^{\circ} \mathrm{C}$ in a thermomixer for $48 \mathrm{~h}$. Aliquots were taken at regular intervals and plated 523 in LB medium for CFU quantification.

\section{Esterase activity assays}

Esterase qualitative assays were performed on either LB plates prepared with $0.5 \%$

526 tributyrin emulsified by sonication (SONICS Vibra-Cell), or NYG plates (peptone, $5 \mathrm{~g} \mathrm{l}^{-1}$; yeast 
527 extract, $5 \mathrm{~g} \mathrm{l}^{-1}$; glycerol, $20 \mathrm{~g} \mathrm{l}^{-1}$, agar, $1 \%$ (Turner et al., 1984)) containing 1\% of Tween 20 and

$5284 \mathrm{mM}$ of $\mathrm{CaCl}_{2}$ (Ramnath et al., 2017). Esterase enzymatic activity was measured

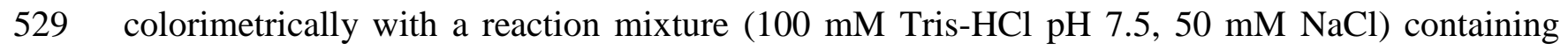

$530500 \mu \mathrm{M}$ of $p \mathrm{NP}-\mathrm{C} 4$ or $200 \mu \mathrm{M}$ of $p \mathrm{NP}-\mathrm{C} 8$ with the addition of 10,20 , or $50 \mu \mathrm{g} \mathrm{m}{ }^{-1}$ of total

531 proteins of purified OMVs in microplate wells. The reactions were incubated at $30{ }^{\circ} \mathrm{C}$ and their

532 absorbance at $400 \mathrm{~nm}$ was measured with a SpectraMax Paradigm microplate reader (Molecular

533 Devices) at regular intervals of time during $4 \mathrm{~h}$.

\section{Protease activity assays}

Protease assays were performed with a protease fluorescent detection kit using casein labeled with fluorescein isothiocyanate (FITC) as the substrate following the manufacturer's instructions (PF0100, Sigma-Aldrich). Briefly, $10 \mu \mathrm{l}$ of the test samples were added to $40 \mu 1$ of FITC-casein in incubation buffer and incubated at $30{ }^{\circ} \mathrm{C}$ for 6 hours. PBS was used as a blank, and the reactions contained 100, 200, or $300 \mu \mathrm{g} \mathrm{ml}^{-1}$ of total proteins of purified OMVs. For some assays, EDTA-free Pierce Protease Inhibitor (A32965, Thermo Scientific) was added to

$541300 \mu \mathrm{g} \mathrm{ml}^{-1}$ samples to a final concentration equivalent to the manufacturer's recommendations

542 (1 tablet for $50 \mathrm{ml}$ of solution). After incubation, undigested substrate was precipitated with the 543 addition of $150 \mu \mathrm{l}$ of trichloroacetic acid $0.6 \mathrm{~N}$ for $30 \mathrm{~min}$ at $37^{\circ} \mathrm{C}$. Aliquots of the supernatants

544 containing FITC-labeled fragments were diluted in assay buffer and analyzed in a black 96-well

545 microplate with a SpectraMax Paradigm microplate reader (Molecular Devices). Relative 546 fluorescence units (RFU) were measured with excitation at $485 \mathrm{~nm}$ and detection at $535 \mathrm{~nm}$. All 547 samples presented RFU measurements substantially above $120 \%$ of the value obtained with the 548 blank (data not shown), which is considered significant according to the kit's manufacturer. 


\section{Acknowledgements}

The authors would like to thank Roberto Cabado Modia Junior and Alfredo Duarte for the

552 technical assistance at the electron microscopy facilities, Thais Viggiani Santana for the

553 assistance at the proteomics facility, and Tania Geraldine Churasacari Vinces for the assistance

554 with the esterase activity experiments.

We thank the Core Facility for Scientific Research - University of São Paulo (CEFAPUSP/BIOMASS) for the proteomic analysis. The authors acknowledge financial support from the

557 São Paulo Research Foundation (FAPESP): grants 2019/00195-2 and 2020/04680-0 to CRG,

$5582017 / 17303-7$ to CSF, 2014/06863-3, 2018/18257-1 and 2018/15549-1 to GP, 2013/07937-8 to

559 SM, 2016/09047-8 to RFdS, 2017/20752-8 to the EMU TQ ICP-MS facility at IPT, and 560 scholarships 2018/21076-9 to GGA, 2017/24301-0 to MMC, 2017/10611-8 to ADP, $5612019 / 12234-2$ to EEL, and 2017/13804-1 to AI. The authors also acknowledge financial support 562 from the Coordenação de Aperfeiçoamento de Pessoal de Nível Superior (CAPES) in the form of 563 scholarships to MMY, IT, and GGA (88887.336498/2019-00), and the Brazilian National

564 Council for Scientific and Technological Development (CNPq) for RP grants 380490/2018-8 and $565 \quad 380939 / 2020-7$.

567 References

568 Aebi, C., Stone, B., Beucher, M., Cope, L.D., Maciver, I., Thomas, S.E. et al. (1996) Expression 569 of the CopB outer membrane protein by Moraxella catarrhalis is regulated by iron and affects 570 iron acquisition from transferrin and lactoferrin. Infect Immun 64: 2024-2030. 
571 Alvarez-Martinez, C.E., Sgro, G.G., Araujo, G.G., Paiva, M.R.N., Matsuyama, B.Y., Guzzo,

572 C.R. et al. (2021) Secrete or perish: The role of secretion systems in Xanthomonas biology.

573 Computational and Structural Biotechnology Journal 19: 279-302.

574 Aparna, G., Chatterjee, A., Sonti, R.V., and Sankaranarayanan, R. (2009) A Cell Wall-

575 Degrading Esterase of Xanthomonas oryzae Requires a Unique Substrate Recognition Module

576 for Pathogenesis on Rice. The Plant Cell 21: 1860-1873.

577 Armenteros, J.J.A., Tsirigos, K.D., Sonderby, C.K., Petersen, T.N., Winther, O., Brunak, S. et al.

578 (2019) SignalP 5.0 improves signal peptide predictions using deep neural networks. Nature

579 Biotechnology 37: 420-+.

580 Assis, R.D.B., Polloni, L.C., Patane, J.S.L., Thakur, S., Felestrino, E.B., Diaz-Caballero, J. et al.

581 (2017) Identification and analysis of seven effector protein families with different adaptive and

582 evolutionary histories in plant-associated members of the Xanthomonadaceae. Scientific Reports

5837.

584 Aznar, A., and Dellagi, A. (2015) New insights into the role of siderophores as triggers of plant

585 immunity: what can we learn from animals? Journal of Experimental Botany 66: 3001-3010.

586 Bahar, O., Mordukhovich, G., Luu, D.D., Schwessinger, B., Daudi, A., Jehle, A.K. et al. (2016)

587 Bacterial Outer Membrane Vesicles Induce Plant Immune Responses. Molecular Plant-Microbe

588 Interactions 29: 374-384.

589 Beltran-Heredia, E., Tsai, F.C., Salinas-Almaguer, S., Cao, F.J., Bassereau, P., and Monroy, F.

590 (2019) Membrane curvature induces cardiolipin sorting. Communications Biology 2.

591 Biller, S.J., Schubotz, F., Roggensack, S.E., Thompson, A.W., Summons, R.E., and Chisholm,

592 S.W. (2014) Bacterial vesicles in marine ecosystems. Science 343: 183-186. 
593 Blanvillain, S., Meyer, D., Boulanger, A., Lautier, M., Guynet, C., Denance, N. et al. (2007)

594 Plant Carbohydrate Scavenging through TonB-Dependent Receptors: A Feature Shared by

595 Phytopathogenic and Aquatic Bacteria. Plos One 2.

596 Bligh, E.G., and Dyer, W.J. (1959) A Rapid Method of Total Lipid Extraction and Purification.

597 Canadian Journal of Biochemistry and Physiology 37: 911-917.

598 Büttner, D., and Bonas, U. (2010) Regulation and secretion of Xanthomonas virulence factors.

599 Fems Microbiology Reviews 34: 107-133.

600 Cao, P., and Wall, D. (2019) Direct visualization of a molecular handshake that governs kin

601 recognition and tissue formation in myxobacteria. Nature Communications 10: 3073.

602 Chaves-Filho, A.B., Pinto, I.F.D., Dantas, L.S., Xavier, A.M., Inague, A., Faria, R.L. et al.

603 (2019) Alterations in lipid metabolism of spinal cord linked to amyotrophic lateral sclerosis.

604 Scientific Reports 9: 11642.

605 Coughlin, R.T., Tonsager, S., and Mcgroarty, E.J. (1983) Quantitation of Metal-Cations Bound

606 to Membranes and Extracted Lipopolysaccharide of Escherichia-Coli. Biochemistry 22: 2002-

6072007.

608 Dejean, G., Blanvillain-Baufume, S., Boulanger, A., Darrasse, A., de Bernonville, T.D., Girard,

609 A.L. et al. (2013) The xylan utilization system of the plant pathogen Xanthomonas campestris pv

610 campestris controls epiphytic life and reveals common features with oligotrophic bacteria and

611 animal gut symbionts. New Phytologist 198: 899-915.

612 Dey, A., and Wall, D. (2014) A Genetic Screen in Myxococcus xanthus Identifies Mutants That

613 Uncouple Outer Membrane Exchange from a Downstream Cellular Response. Journal of

614 Bacteriology 196: 4324-4332. 
615 Dow, J.M., Clarke, B.R., Milligan, D.E., Tang, J.L., and Daniels, M.J. (1990) Extracellular

616 Proteases from Xanthomonas campestris pv. Campestris, the Black Rot Pathogen. Applied and

617 Environmental Microbiology 56: 2994-2998.

618 Elhenawy, W., Debelyy, M.O., and Feldman, M.F. (2014) Preferential Packing of Acidic

619 Glycosidases and Proteases into Bacteroides Outer Membrane Vesicles. Mbio 5.

620 Evans, A.G.L., Davey, H.M., Cookson, A., Currinn, H., Cooke-Fox, G., Stanczyk, P.J., and

621 Whitworth, D.E. (2012) Predatory activity of Myxococcus xanthus outer-membrane vesicles and

622 properties of their hydrolase cargo. Microbiology 158: 2742-2752.

623 Feitosa-Junior, O.R., Stefanello, E., Zaini, P.A., Nascimento, R., Pierry, P.M., Dandekar, A.M. et

624 al. (2019) Proteomic and Metabolomic Analyses of Xylella fastidiosa OMV-Enriched Fractions

625 Reveal Association with Virulence Factors and Signaling Molecules of the DSF Family.

626 Phytopathology 109: 1344-1353.

627 Fett, W.F., Gerard, H.C., Moreau, R.A., Osman, S.F., and Jones, L.E. (1992) Screening of

628 Nonfilamentous Bacteria for Production of Cutin-Degrading Enzymes. Applied and

629 Environmental Microbiology 58: 2123-2130.

630 Figaj, D., Ambroziak, P., Przepiora, T., and Skorko-Glonek, J. (2019) The Role of Proteases in

631 the Virulence of Plant Pathogenic Bacteria. International Journal of Molecular Sciences 20.

632 Fischer, T., Schorb, M., Reintjes, G., Kolovou, A., Santarella-Mellwig, R., Markert, S. et al.

633 (2019) Biopearling of Interconnected Outer Membrane Vesicle Chains by a Marine

634 Flavobacterium. Applied and Environmental Microbiology 85: e00829-00819.

635 Franceschini, A., Szklarczyk, D., Frankild, S., Kuhn, M., Simonovic, M., Roth, A. et al. (2013)

636 STRING v9.1: protein-protein interaction networks, with increased coverage and integration.

637 Nucleic Acids Research 41: D808-D815. 
638 Guerrero-Mandujano, A., Hernandez-Cortez, C., Ibarra, J.A., and Castro-Escarpulli, G. (2017)

639 The outer membrane vesicles: Secretion system type zero. Traffic 18: 425-432.

640 Hampton, C.M., Guerrero-Ferreira, R.C., Storms, R.E., Taylor, J.V., Yi, H., Gulig, P.A., and

641 Wright, E.R. (2017) The Opportunistic Pathogen Vibrio vulnificus Produces Outer Membrane

642 Vesicles in a Spatially Distinct Manner Related to Capsular Polysaccharide. Frontiers in

\section{Microbiology 8.}

644 Hase, C.C., and Finkelstein, R.A. (1993) Bacterial Extracellular Zinc-Containing

645 Metalloproteases. Microbiological Reviews 57: 823-837.

646 Hassani, M.A., Duran, P., and Hacquard, S. (2018) Microbial interactions within the plant

647 holobiont. Microbiome 6.

648 Hellman, J., Loiselle, P.M., Zanzot, E.M., Allaire, J.E., Tehan, M.M., Boyle, L.A. et al. (2000)

649 Release of gram-negative outer-membrane proteins into human serum and septic rat blood and

650 their interactions with immunoglobulin in antiserum to Escherichia coli J5. J Infect Dis 181:

$651 \quad 1034-1043$.

652 Hickey, C.A., Kuhn, K.A., Donermeyer, D.L., Porter, N.T., Jin, C., Cameron, E.A. et al. (2015)

653 Colitogenic Bacteroides thetaiotaomicron Antigens Access Host Immune Cells in a Sulfatase-

654 Dependent Manner via Outer Membrane Vesicles. Cell Host Microbe 17: 672-680.

655 Hou, S.G., Jamieson, P., and He, P. (2018) The cloak, dagger, and shield: proteases in plant656 pathogen interactions. Biochemical Journal 475: 2491-2509.

657 Katsir, L., and Bahar, O. (2017) Bacterial outer membrane vesicles at the plant-pathogen 658 interface. Plos Pathogens 13. 
Kim, Y.R., Kim, B.U., Kim, S.Y., Kim, C.M., Na, H.S., Koh, J.T. et al. (2010) Outer membrane vesicles of Vibrio vulnificus deliver cytolysin-hemolysin Vvha into epithelial cells to induce cytotoxicity. Biochemical and Biophysical Research Communications 399: 607-612.

662 Krewulak, K.D., and Vogel, H.J. (2011) TonB or not TonB: is that the question? Biochemistry and Cell Biology 89: 87-97.

664 Lappann, M., Otto, A., Becher, D., and Vogel, U. (2013) Comparative proteome analysis of 665 spontaneous outer membrane vesicles and purified outer membranes of Neisseria meningitidis. $J$ Bacteriol 195: 4425-4435.

667 Lin, T.Y., and Weibel, D.B. (2016) Organization and function of anionic phospholipids in 668 bacteria. Applied Microbiology and Biotechnology 100: 4255-4267.

669 Louden, B.C., Haarmann, D., and Lynne, A.M. (2011) Use of Blue Agar CAS Assay for

670 Siderophore Detection. Journal of Microbiology \&amp; Biology Education 12: 51-53.

671 Macdonald, I.A., and Kuehn, M.J. (2013) Stress-induced outer membrane vesicle production by

672 Pseudomonas aeruginosa. J Bacteriol 195: 2971-2981.

673 Maredia, R., Devineni, N., Lentz, P., Dallo, S.F., Yu, J., Guentzel, N. et al. (2012) Vesiculation

674 from Pseudomonas aeruginosa under SOS. ScientificWorldJournal 2012: 402919.

675 McBroom, A.J., and Kuehn, M.J. (2007) Release of outer membrane vesicles by Gram-negative 676 bacteria is a novel envelope stress response. Mol Microbiol 63: 545-558.

677 McCaig, W.D., Koller, A., and Thanassi, D.G. (2013) Production of Outer Membrane Vesicles 678 and Outer Membrane Tubes by Francisella novicida. Journal of Bacteriology 195: 1120-1132.

679 Nascimento, R., Gouran, H., Chakraborty, S., Gillespie, H.W., Almeida-Souza, H.O., Tu, A. et 680 al. (2016) The Type II Secreted Lipase/Esterase LesA is a Key Virulence Factor Required for 681 Xylella fastidiosa Pathogenesis in Grapevines. Scientific Reports 6. 
682 Ou, S.H. (1985) Bacterial leaf blight. In Rice Diseases: Commonwealth Mycological Institute,

683 pp. 61-96.

684 Pirbadian, S., Barchinger, S.E., Leung, K.M., Byun, H.S., Jangir, Y., Bouhenni, R.A. et al.

685 (2014) Shewanella oneidensis MR-1 nanowires are outer membrane and periplasmic extensions

686 of the extracellular electron transport components. Proceedings of the National Academy of

687 Sciences of the United States of America 111: 12883-12888.

688 Pirbadian, S., Barchinger, S.E., Leung, K.M., Byun, H.S., Jangir, Y., Bouhenni, R.A. et al.

689 (2015) Bacterial Nanowires of Shewanella Oneidensis MR-1 are Outer Membrane and

690 Periplasmic Extensions of the Extracellular Electron Transport Components. Biophysical Journal

691 108: 368a-368a.

692 Planas-Iglesias, J., Dwarakanath, H., Mohammadyani, D., Yanamala, N., Kagan, V.E., and

693 Klein-Seetharaman, J. (2015) Cardiolipin Interactions with Proteins. Biophysical Journal 109:

$694 \quad 1282-1294$.

695 Rakoff-Nahoum, S., Coyne, M.J., and Comstock, L.E. (2014) An ecological network of

696 polysaccharide utilization among human intestinal symbionts. Curr Biol 24: 40-49.

697 Ramnath, L., Sithole, B., and Govinden, R. (2017) Identification of lipolytic enzymes isolated

698 from bacteria indigenous to Eucalyptus wood species for application in the pulping industry.

699 Biotechnology Reports 15: 114-124.

700 Remis, J.P., Wei, D.G., Gorur, A., Zemla, M., Haraga, J., Allen, S. et al. (2014) Bacterial social

701 networks: structure and composition of Myxococcus xanthus outer membrane vesicle chains.

702 Environmental Microbiology 16: 598-610. 
703 Renner, L.D., and Weibel, D.B. (2011) Cardiolipin microdomains localize to negatively curved

704 regions of Escherichia coli membranes. Proceedings of the National Academy of Sciences of the

705 United States of America 108: 6264-6269.

706 Sampath, V., McCaig, W.D., and Thanassi, D.G. (2018) Amino acid deprivation and central

707 carbon metabolism regulate the production of outer membrane vesicles and tubes by Francisella.

708 Molecular Microbiology 107: 523-541.

709 Schlechter, R.O., Miebach, M., and Remus-Emsermann, M.N.P. (2019) Driving factors of

710 epiphytic bacterial communities: A review. Journal of Advanced Research 19: 57-65.

711 Schwechheimer, C., and Kuehn, M.J. (2013) Synthetic effect between envelope stress and lack

712 of outer membrane vesicle production in Escherichia coli. J Bacteriol 195: 4161-4173.

713 Schwechheimer, C., and Kuehn, M.J. (2015) Outer-membrane vesicles from Gram-negative

714 bacteria: biogenesis and functions. Nature Reviews Microbiology 13: 605-619.

715 Schwyn, B., and Neilands, J.B. (1987) Universal Chemical-Assay for the Detection and 716 Determination of Siderophores. Analytical Biochemistry 160: 47-56.

717 Sgro, G.G., Oka, G.U., Souza, D.P., Cenens, W., Bayer-Santos, E., Matsuyama, B.Y. et al. 718 (2019) Bacteria-Killing Type IV Secretion Systems. Frontiers in Microbiology 10.

719 Shetty, A., Chen, S.C., Tocheva, E.I., Jensen, G.J., and Hickey, W.J. (2011) Nanopods: A New 720 Bacterial Structure and Mechanism for Deployment of Outer Membrane Vesicles. Plos One 6.

721 Sidhu, V.K., Vorholter, F.J., Niehaus, K., and Watt, S.A. (2008) Analysis of outer membrane 722 vesicle associated proteins isolated from the plant pathogenic bacterium Xanthomonas 723 campestris pv. campestris. Bmc Microbiology 8.

724 Sjöström, A.E., Sandblad, L., Uhlin, B.E., and Wai, S.N. (2015) Membrane vesicle-mediated 725 release of bacterial RNA. Scientific Reports 5. 
726 Solé, M., Scheibner, F., Hoffmeister, A.K., Hartmann, N., Hause, G., Rother, A. et al. (2015)

727 Xanthomonas campestris pv. vesicatoria Secretes Proteases and Xylanases via the Xps Type II

728 Secretion System and Outer Membrane Vesicles. Journal of Bacteriology 197: 2879-2893.

729 Sorice, M., Manganelli, V., Matarrese, P., Tinari, A., Misasi, R., Malorni, W., and Garofalo, T.

730 (2009) Cardiolipin-enriched raft-like microdomains are essential activating platforms for

731 apoptotic signals on mitochondria. Febs Letters 583: 2447-2450.

732 Tamir-Ariel, D., Rosenberg, T., Navon, N., and Burdman, S. (2012) A secreted lipolytic enzyme

733 from Xanthomonas campestris pv. vesicatoria is expressed in planta and contributes to its

734 virulence. Molecular Plant Pathology 13: 556-567.

735 Tashiro, Y., Inagaki, A., Shimizu, M., Ichikawa, S., Takaya, N., Nakajima-Kambe, T. et al.

736 (2011) Characterization of Phospholipids in Membrane Vesicles Derived from Pseudomonas

737 aeruginosa. Bioscience Biotechnology and Biochemistry 75: 605-607.

738 Tayi, L., Maku, R.V., Patel, H.K., and Sonti, R.V. (2016) Identification of Pectin Degrading

739 Enzymes Secreted by Xanthomonas oryzae pv. oryzae and Determination of Their Role in

$740 \quad$ Virulence on Rice. Plos One 11.

741 Toledo, A., Coleman, J.L., Kuhlow, C.J., Crowley, J.T., and Benach, J.L. (2012) The enolase of

742 Borrelia burgdorferi is a plasminogen receptor released in outer membrane vesicles. Infect

743 Immun 80: 359-368.

744 Toyofuku, M., Nomura, N., and Eberl, L. (2019) Types and origins of bacterial membrane 745 vesicles. Nature Reviews Microbiology 17: 13-24.

746 Turner, P., Barber, C., and Daniels, M. (1984) Behavior of the Transposons Tn5 and Tn7 in

747 Xanthomonas-Campestris Pv Campestris. Molecular \& General Genetics 195: 101-107. 
748 Tyanova, S., Temu, T., and Cox, J. (2016) The MaxQuant computational platform for mass

749 spectrometry-based shotgun proteomics. Nature Protocols 11: 2301-2319.

750 Ueda, H., Kurose, D., Kugimiya, S., Mitsuhara, I., Yoshida, S., Tabata, J. et al. (2018) Disease

751 severity enhancement by an esterase from non-phytopathogenic yeast Pseudozyma antarctica and

752 its potential as adjuvant for biocontrol agents. Scientific Reports $\mathbf{8}$.

753 Yu, N.Y., Wagner, J.R., Laird, M.R., Melli, G., Rey, S., Lo, R. et al. (2010) PSORTb 3.0:

754 improved protein subcellular localization prediction with refined localization subcategories and

755 predictive capabilities for all prokaryotes. Bioinformatics 26: 1608-1615.

756 Zwarycz, A.S., Livingstone, P.G., and Whitworth, D.E. (2020) Within-species variation in OMV

757 cargo proteins: the Myxococcus xanthus OMV pan-proteome. Molecular Omics 16: 387-397. 

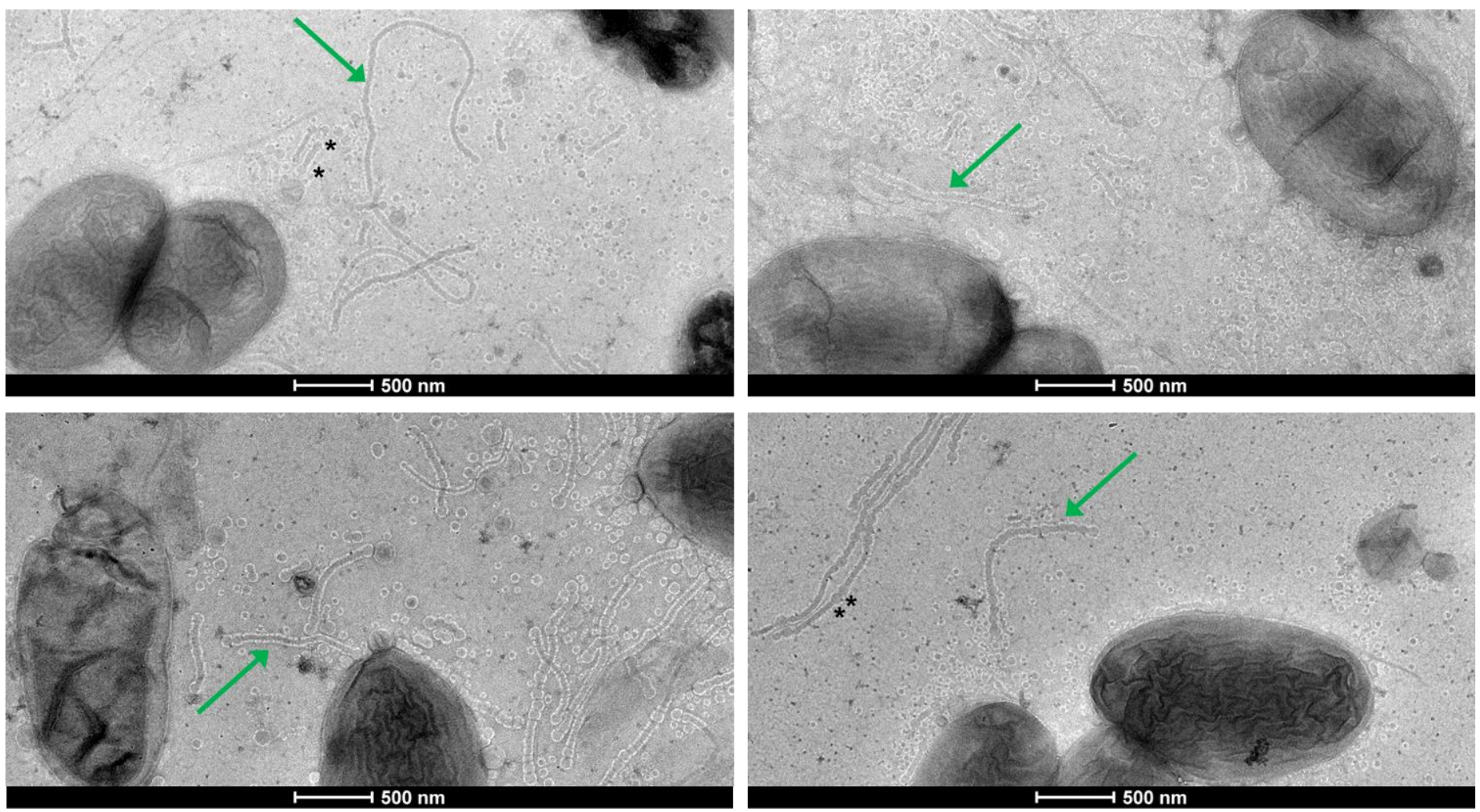

Fig. 1. Outer membrane tubes and vesicles from X. citri. Cells were grown in SB with

761 agar $0.6 \%$ and imaged by negative stain TEM. The green arrows point to examples of the outer

762 membrane tubes that can be seen in the images. Asterisks $\left(^{*}\right)$ indicate some occurrences of larger

763 vesicles at the tips or within tubes. 

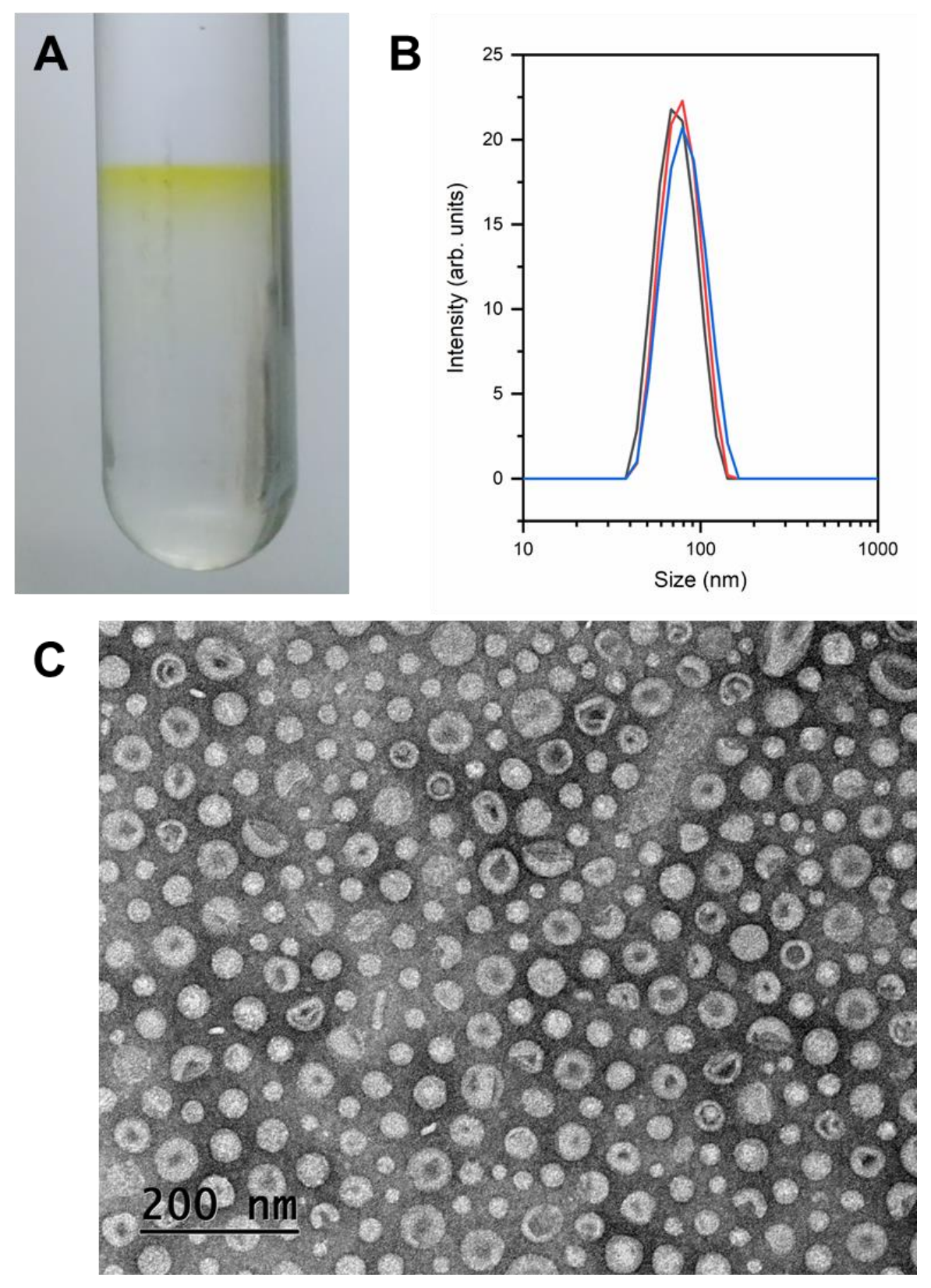

Fig. 2. Purification and characterization of the $X$. citri outer membrane vesicles (OMVs).

767 Vesicles were retrieved as a yellow band from the density gradient centrifugation tubes (A). The

768 vesicle size distribution was determined by DLS and observed to range from about 40 to $150 \mathrm{~nm}$

769 in diameter, with a peak near $75 \mathrm{~nm}(\mathrm{~B})$. Observation by negative stain TEM confirmed the

770 purification of the OMVs, allowing the evaluation of their size, morphology, and lack of

771 contaminating cells $(\mathrm{C})$. 

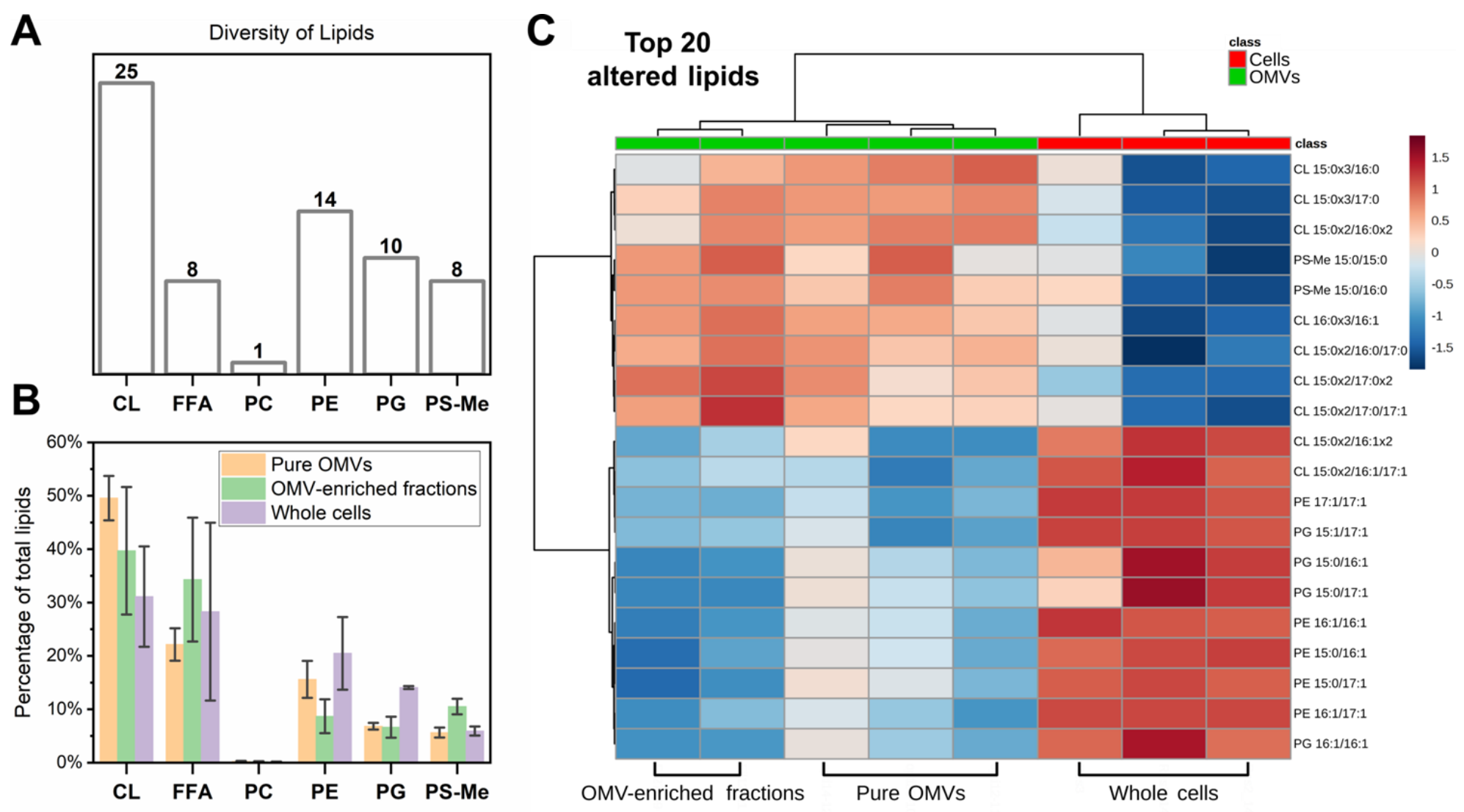

Fig. 3. Lipidomic analysis of $X$. citri whole cells and OMVs. A total of 66 different lipids

773 were identified in the samples, divided into 6 subclasses: cardiolipin (CL), free fatty acids (FFA),

774 phosphatidylcholine (PC), phosphatidylethanolamine (PE), phosphatidylglycerol (PG),

775 methylated-phosphatidylserine (PS-Me), shown in panel A. The proportion of each lipid subclass

776 varied between the different samples: Pure OMVs, OMV-enriched fractions (partially purified),

777 and whole cells (B). The 20 most altered lipids between the different samples (identified from a

778 volcano plot analysis, fold-change $>1.5, \mathrm{p}<0.05$ evaluated by FDR-adjusted t-test, Fig. S2)

779 were clustered in a heatmap (according to one-way ANOVA), revealing the vesicles are enriched

780 in saturated cardiolipins in comparison to the cells, while being relatively impoverished in a

781 number of different unsaturated lipid species (C). The notation used to represent the lipids from

782 the different subclasses gives the number of carbon atoms and of double bonds separated by a

783 colon for each acyl chain, which in turn are separated by a slash. 
A $\mathrm{kDa}$

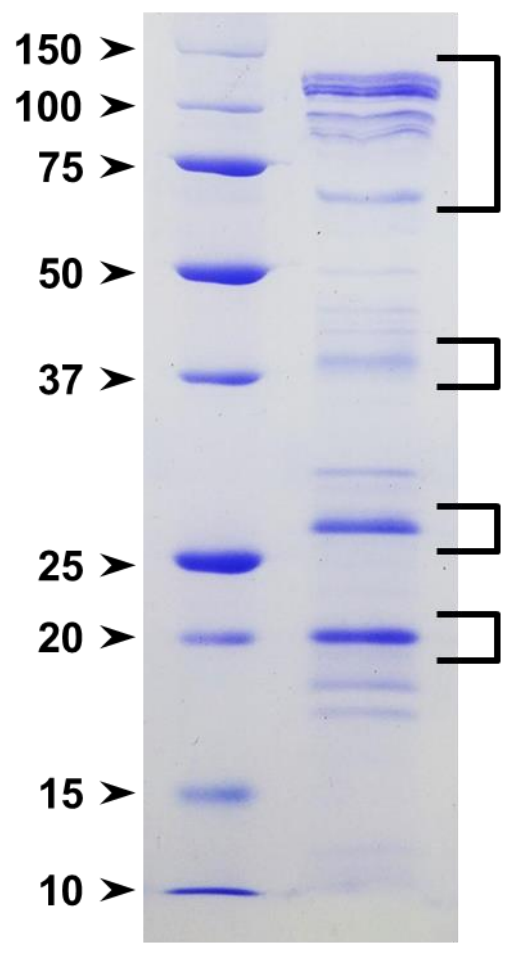

B

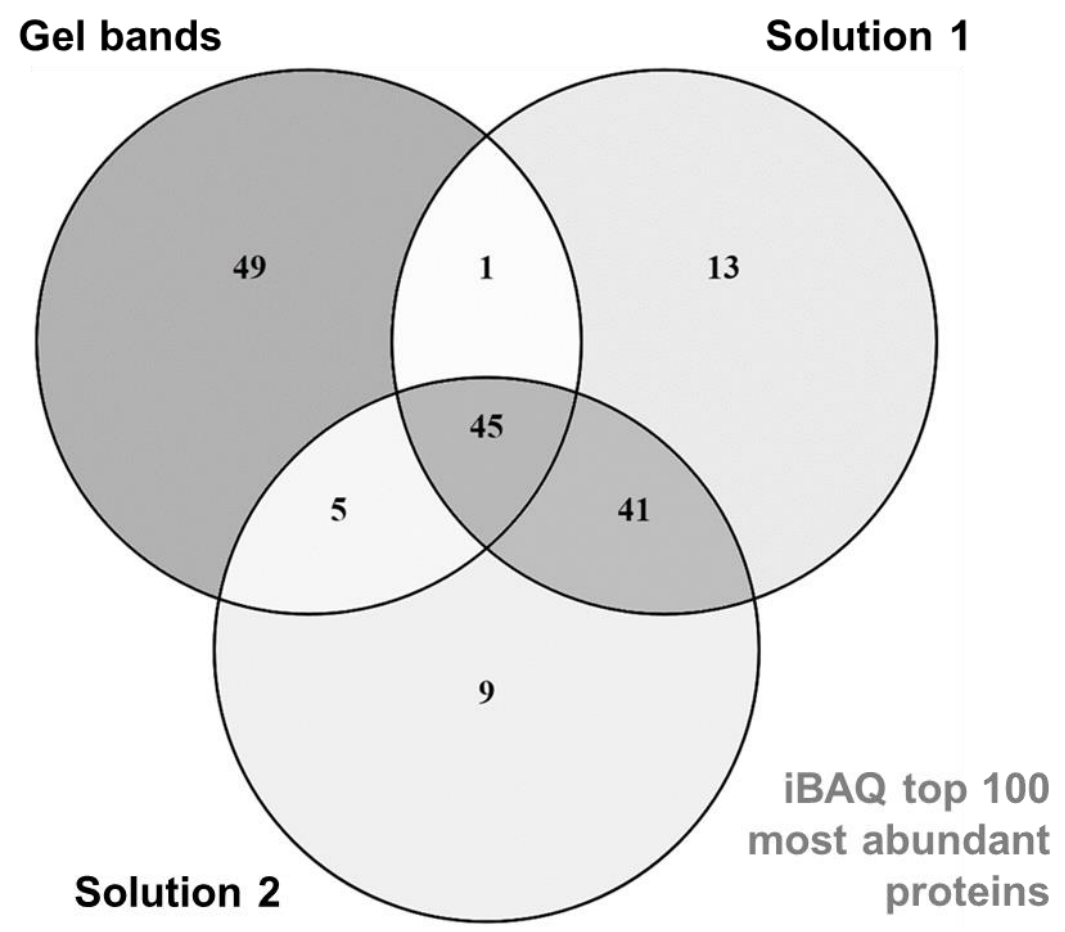

Fig. 4. Proteomic analysis of $X$. citri OMV samples. Panel A shows characteristic protein

786 bands associated with the purified OMVs that could be observed in $15 \%$ Tris-Glycine SDS-

787 PAGE gels. Four regions containing the main bands (square brackets) were processed by in-gel

788 digestion for proteomic analyses; their data were combined ("gel bands") and compared to two

789 samples of pure OMV suspensions processed by in-solution digestion ("solution 1" and "solution

790 2"). Panel B presents a Venn diagram displaying the intersection of the top 100 most abundant

791 proteins for each sample determined by their iBAQ values. 
A

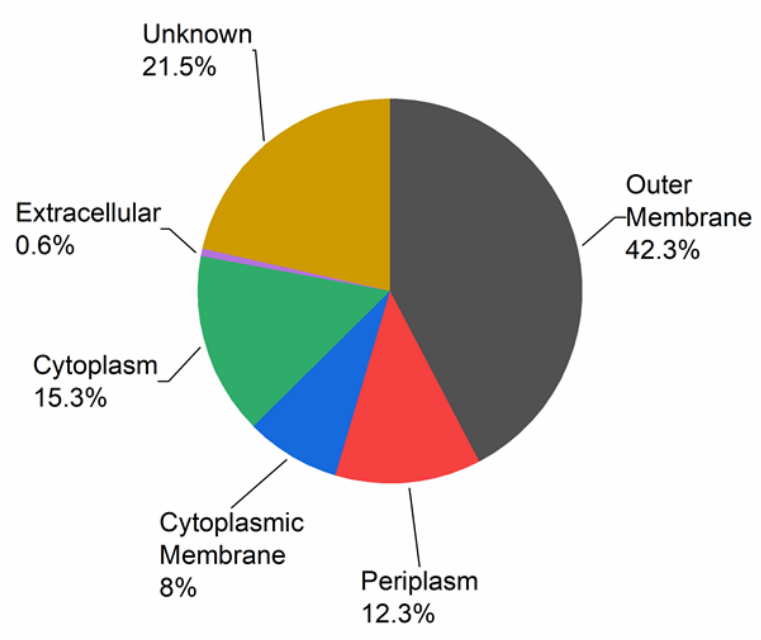

B

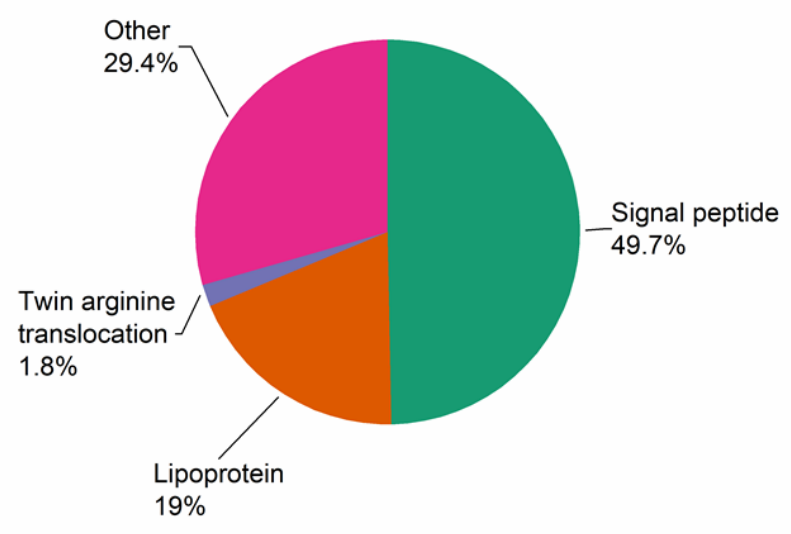

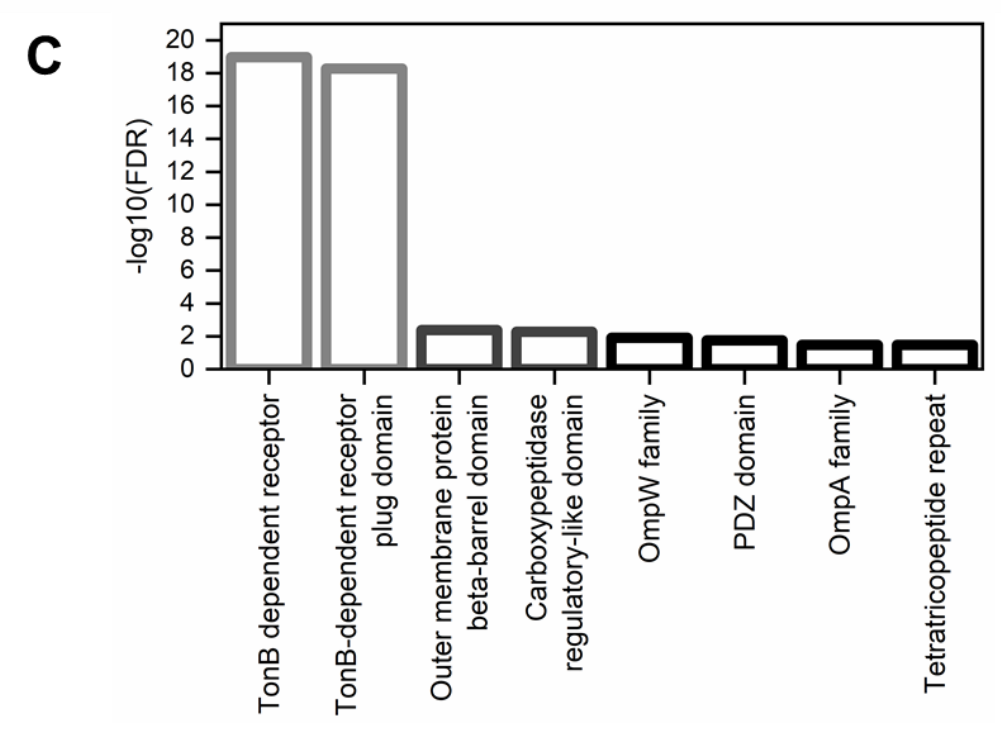

794 Fig. 5. Subcellular localization and domain enrichment of the most abundant proteins

795 identified in the purified X. citri OMV samples. Panel A presents the subcellular protein 796 localization predicted by PSORTb, manually curated based on sequence annotations, while panel

797 B shows their secretion mechanisms predicted by SignalP. Panel C displays the most 798 significantly enriched Pfam domains found in the OMVs compared to the X. citri pv. citri 306 799 genome. The lowest false discovery rate (FDR), thus the highest - $\log 10$ (FDR), was observed for 800 TonB-dependent receptor domains (Pfam family PF00593). These analyses were performed with 
bioRxiv preprint doi: https://doi.org/10.1101/2021.04.26.441564; this version posted April 28, 2021. The copyright holder for this preprint (which was not certified by peer review) is the author/funder, who has granted bioRxiv a license to display the preprint in perpetuity. It is made available under aCC-BY-NC 4.0 International license.

801 the combination of the top 100 proteins with the highest iBAQ values from the different samples

802 analyzed by proteomics (gel bands, solution 1, solution 2), resulting in a list of 163 non803 redundant proteins (Table S1). 


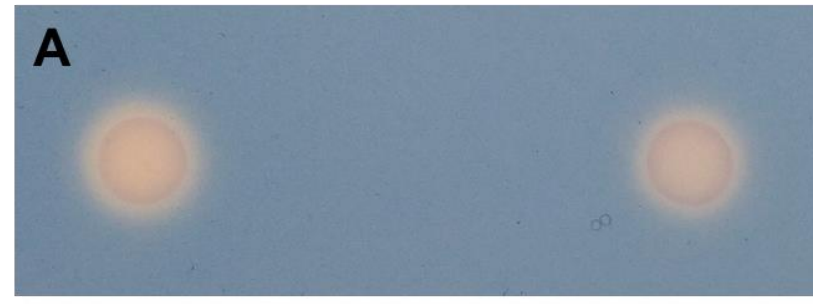

C

B
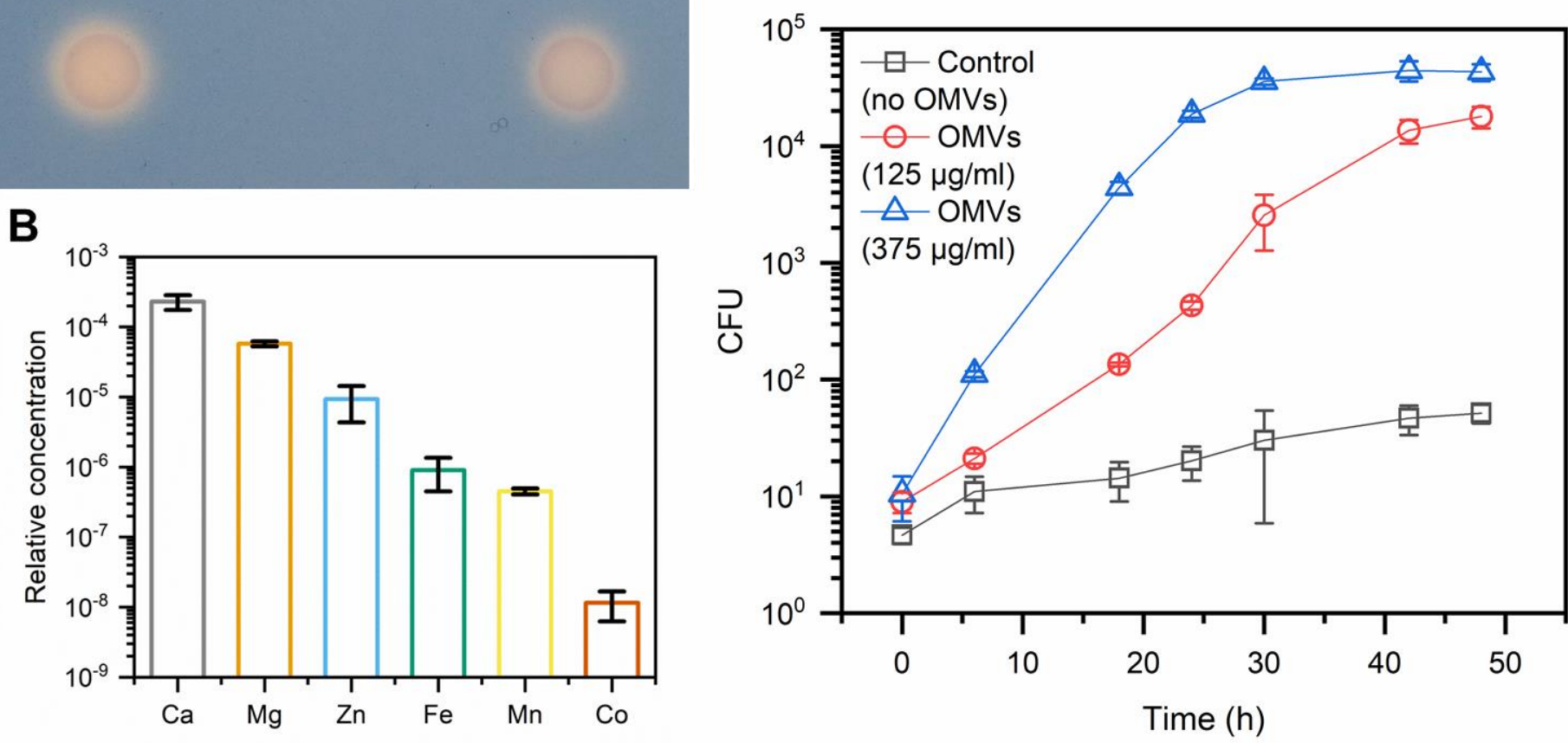

804

Fig. 6. $X$. citri OMVs carry essential metals and can be incorporated by cells.

806 Siderophores were potentially detected in the OMVs by discoloration of the medium in CAS

807 plates where vesicles were applied (A). Elemental analysis of the OMVs revealed the presence of

808 biologically important metals in the samples, including iron and zinc. The relative concentration

809 (y-axis) was calculated by the ratio between the mass fraction values for each element and the

810 carbon content. The oxidation state of each element was not determined. (B). X. citri can use

811 OMVs as the sole carbon source for growth, indicating that the content of the vesicles is

812 available for incorporation by cells (C). Different OMV concentrations, measured by their

813 protein content, were added to tubes with M9 medium without other carbon source and a

814 substantial increase in CFU was observed after incubation. 

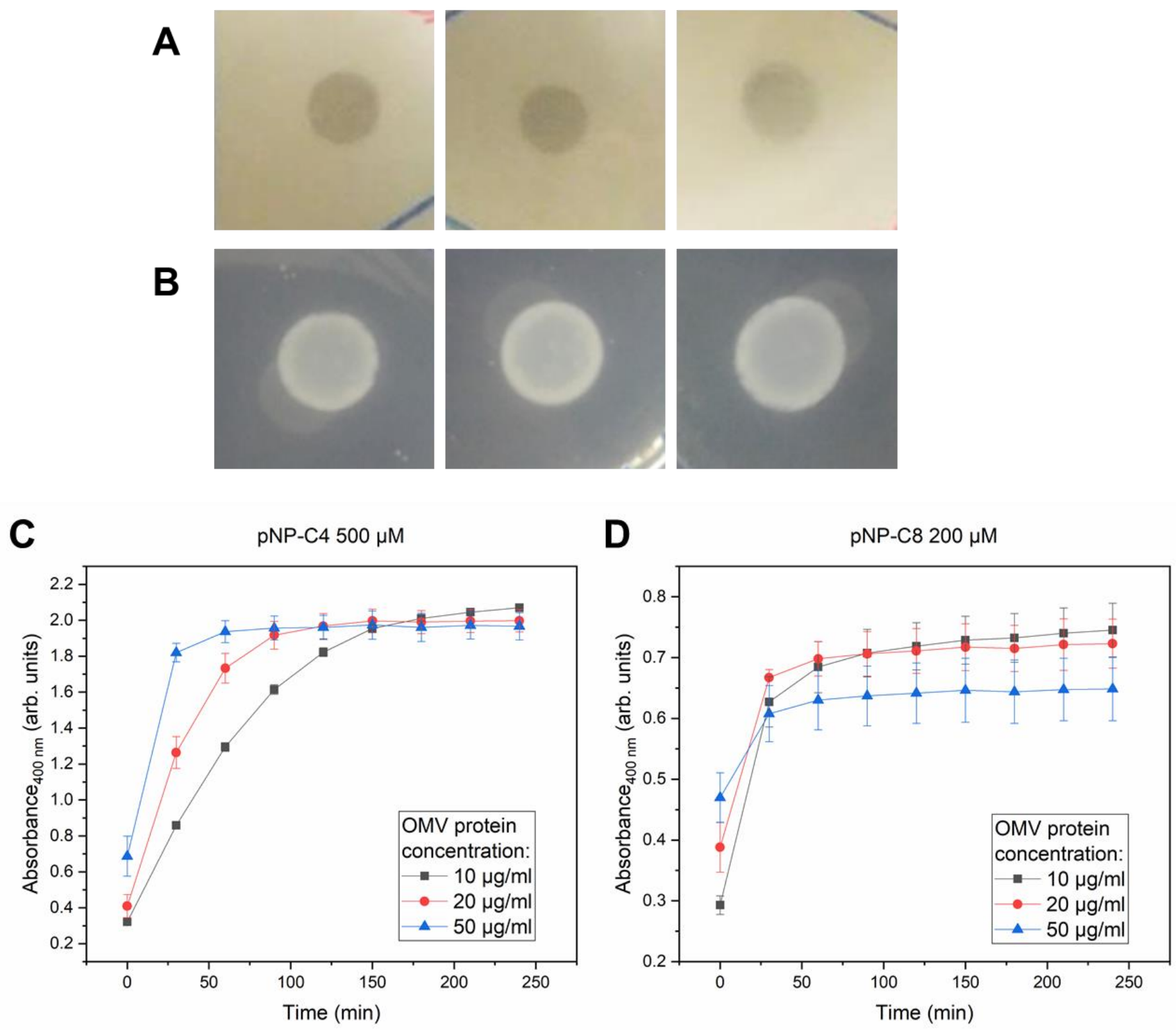

816

Fig. 7. X. citri OMVs present esterase activity against a broad range of substrates. In

818 qualitative esterase activity assays on agar plates, different purified OMV samples were able to

819 create a clear halo in plates emulsified with the triglyceride tributirin (A) and to generate opaque

820 white precipitates in plates containing Tween 20 and $\mathrm{CaCl}_{2}$ (B). These results indicate the

821 hydrolysis of the respective substrates in the plates. Different OMV concentrations, measured by 
bioRxiv preprint doi: https://doi.org/10.1101/2021.04.26.441564; this version posted April 28, 2021. The copyright holder for this preprint (which was not certified by peer review) is the author/funder, who has granted bioRxiv a license to display the preprint in perpetuity. It is made available under aCC-BY-NC 4.0 International license.

822 their total protein content, were able to hydrolyze $p$ NP-C4 (panel C) and $p$ NP-C8 (panel D) in

823 colorimetric assays, indicated by the increase in absorbance at $400 \mathrm{~nm}$ during incubation.

824 


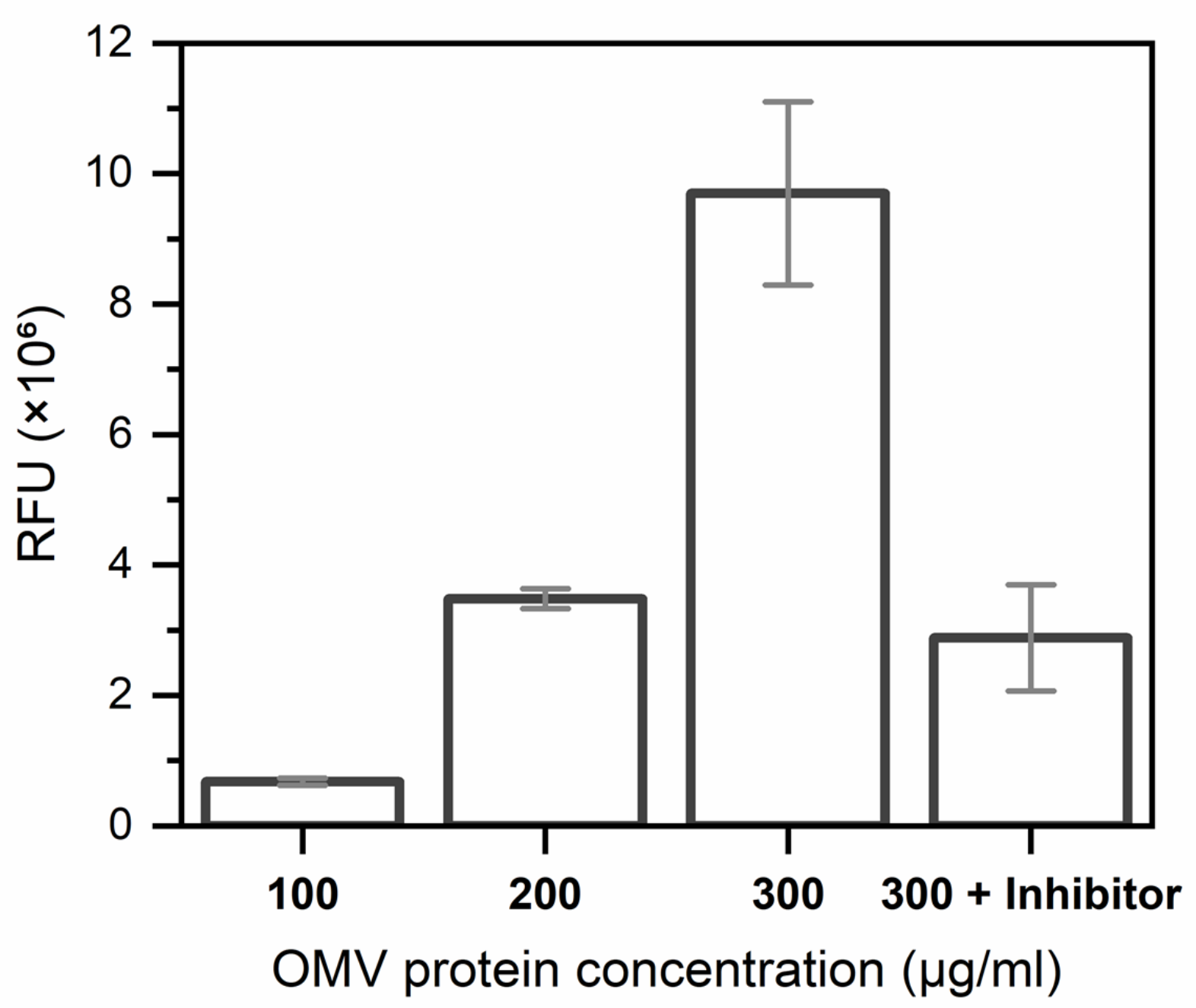

Fig. 8. $X$. citri OMVs present protease activity. A protease fluorescent detection kit was

827 used to detect the activity of purified OMVs at different concentrations, measured as relative

828 fluorescence units (RFU). Addition of an EDTA-free protease inhibitor to samples with the

829 highest OMV concentration tested lead to substantial decrease in the observed enzymatic 830 activity. The fluorescence from blank (phosphate buffered saline) was subtracted from all 831 samples. 
Data Set S1. Proteomic data for purified X. citri OMVs, containing details of the filtered

834 proteins identified for the duplicate of in-solution digestions, including their iBAQ values

835 (XLSX file).

836

837

Data Set S2. Proteomic data for purified X. citri OMVs, containing details of the filtered

838 proteins identified for the in-gel digestion, including their iBAQ values (XLSX file).

839

840 
842 values from the different purified $X$. citri OMV samples (gel bands and a replicate of samples in

843 solution, Fig. 4), resulting in a list of 163 non-redundant proteins. UniProt annotations are

844 presented for each sequence.

\begin{tabular}{|c|c|c|c|c|c|}
\hline $\begin{array}{l}\text { UniProt } \\
\text { ID }\end{array}$ & $\begin{array}{l}\text { Gene } \\
\text { names }\end{array}$ & Locus tags & Protein names (UniProt) & $\begin{array}{l}\text { Pfam } \\
\text { domains }\end{array}$ & InterPro domains \\
\hline Q8PRF7 & & XAC0006 & $\begin{array}{l}\text { Peptidase_M48 domain-containing } \\
\text { protein }\end{array}$ & PF01435 & IPR001915 \\
\hline Q8PRF6 & & XAC0007 & $\begin{array}{l}\text { TPR_REGION domain-containing } \\
\text { protein }\end{array}$ & PF13181 & $\begin{array}{l}\text { IPR013026; IPR011990; } \\
\text { IPR019734 }\end{array}$ \\
\hline Q8PRF4 & exbB & ХАC0009 & Biopolymer transport ExbB protein & PF01618 & IPR002898 \\
\hline Q8PRE0 & ctp & XАC0023 & Carboxyl-terminal protease & $\begin{array}{l}\text { PF13180; } \\
\text { PF03572 }\end{array}$ & $\begin{array}{l}\text { IPR029045; IPR001478; } \\
\text { IPR036034; IPR004447; } \\
\text { IPR005151 }\end{array}$ \\
\hline Q8PRD3 & egl & XAC0030 & Cellulase & PF00150 & $\begin{array}{l}\text { IPR001547; IPR018087; } \\
\text { IPR017853 }\end{array}$ \\
\hline Q8PRC7 & & ХAC0036 & Uncharacterized protein & & \\
\hline Q8PR40 & yncD & XAC0126 & Iron transporter & $\begin{array}{l}\text { PF07715; } \\
\text { PF00593 }\end{array}$ & $\begin{array}{l}\text { IPR039426; IPR012910; } \\
\text { IPR037066; IPR000531; } \\
\text { IPR036942 }\end{array}$ \\
\hline Q8PQZ3 & fpvA & XAC0176 & Ferripyoverdine receptor & $\begin{array}{l}\text { PF07715; } \\
\text { PF00593 }\end{array}$ & $\begin{array}{l}\text { IPR012910; IPR037066; } \\
\text { IPR039423; IPR000531; } \\
\text { IPR036942; IPR010105 }\end{array}$ \\
\hline Q8PQZ2 & & XAC0177 & PNPLA domain-containing protein & PF01734 & IPR016035; IPR002641 \\
\hline Q8PQX9 & & XAC0190 & Uncharacterized protein & & IPR011990 \\
\hline Q8PQW2 & уојМ & ХАC0209 & $\begin{array}{l}\text { Superoxide dismutase [Cu-Zn] (EC } \\
\text { 1.15.1.1) }\end{array}$ & PF00080 & $\begin{array}{l}\text { IPR036423; IPR024134; } \\
\text { IPR018152; IPR001424 }\end{array}$ \\
\hline Q8PQU8 & & XАC0223 & Uncharacterized protein & & IPR026364; IPR023614 \\
\hline Q8PQT9 & & XАC0232 & Uncharacterized protein & PF13698 & IPR025294 \\
\hline Q8PQQ0 & & XAC0272 & Uncharacterized protein & & \\
\hline Q8PQN4 & & ХАC0289 & Uncharacterized protein & & IPR016980; IPR029063 \\
\hline Q8NL21 & rplM & XAC0487 & 50S ribosomal protein L13 & PF00572 & $\begin{array}{l}\text { IPR005822; IPR005823; } \\
\text { IPR023563; IPR036899 }\end{array}$ \\
\hline Q8PPZ1 & groL & XAC0542 & $\begin{array}{l}60 \mathrm{kDa} \text { chaperonin (GroEL protein) } \\
\text { (Protein Cpn60) }\end{array}$ & PF00118 & $\begin{array}{l}\text { IPR018370; IPR001844; } \\
\text { IPR002423; IPR027409; } \\
\text { IPR027413; IPR027410 }\end{array}$ \\
\hline Q8PPR2 & & ХAC0623 & Uncharacterized protein & PF04338 & IPR007433 \\
\hline Q8PPM3 & rlpA & XAC0663 & $\begin{array}{l}\text { Endolytic peptidoglycan } \\
\text { transglycosylase RlpA (EC 4.2.2.-) }\end{array}$ & $\begin{array}{l}\text { PF03330; } \\
\text { PF05036 }\end{array}$ & $\begin{array}{l}\text { IPR034718; IPR009009; } \\
\text { IPR036908; IPR012997; } \\
\text { IPR007730; IPR036680 }\end{array}$ \\
\hline Q8PPM2 & dacC & XAC0664 & $\begin{array}{l}\text { Serine-type D-Ala-D-Ala } \\
\text { carboxypeptidase (EC 3.4.16.4) }\end{array}$ & $\begin{array}{l}\text { PF07943; } \\
\text { PF00768 }\end{array}$ & $\begin{array}{l}\text { IPR012338; IPR015956; } \\
\text { IPR018044; IPR012907; }\end{array}$ \\
\hline
\end{tabular}




\begin{tabular}{|c|c|c|c|c|c|}
\hline & & & & & IPR037167; IPR001967 \\
\hline Q8PPK9 & & XAC0677 & Uncharacterized protein & PF10001 & IPR018718 \\
\hline Q8PPK4 & & XAC0682 & BON domain-containing protein & PF04972 & IPR007055; IPR014004 \\
\hline Q8PPJ6 & fecA & XAC0690 & TonB-dependent receptor & $\begin{array}{l}\text { PF07715; } \\
\text { PF00593 }\end{array}$ & $\begin{array}{l}\text { IPR012910; IPR037066; } \\
\text { IPR039423; IPR000531; } \\
\text { IPR036942 }\end{array}$ \\
\hline Q8PPH0 & fyuA & XAC0716 & TonB-dependent receptor & $\begin{array}{l}\text { PF07715; } \\
\text { PF00593 }\end{array}$ & $\begin{array}{l}\text { IPR012910; IPR037066; } \\
\text { IPR000531; IPR036942; } \\
\text { IPR010104 }\end{array}$ \\
\hline Q8PPD9 & & XAC0747 & Uncharacterized protein & & IPR023614 \\
\hline Q8PPC1 & & XAC0765 & Uncharacterized protein & PF04348 & IPR007443; IPR028082 \\
\hline Q8PP23 & surA & XAC0865 & $\begin{array}{l}\text { Chaperone SurA (Peptidyl-prolyl cis- } \\
\text { trans isomerase SurA) (PPIase SurA) } \\
\text { (EC 5.2.1.8) (Rotamase SurA) }\end{array}$ & $\begin{array}{l}\text { PF00639; } \\
\text { PF09312 }\end{array}$ & $\begin{array}{l}\text { IPR000297; IPR023034; } \\
\text { IPR015391; IPR027304 }\end{array}$ \\
\hline Q8PP00 & gfo & XAC0888 & Glucose-fructose oxidoreductase & $\begin{array}{l}\text { PF01408; } \\
\text { PF02894 }\end{array}$ & $\begin{array}{l}\text { IPR004104; IPR008354; } \\
\text { IPR036291; IPR000683 }\end{array}$ \\
\hline Q8PNT4 & $\mathrm{rplK}$ & XAC0961 & 50S ribosomal protein L11 & $\begin{array}{l}\text { PF00298; } \\
\text { PF03946 }\end{array}$ & $\begin{array}{l}\text { IPR000911; IPR036796; } \\
\text { IPR006519; IPR020783; } \\
\text { IPR036769; IPR020785; } \\
\text { IPR020784 }\end{array}$ \\
\hline Q8PNS2 & rplW & XAC0974 & 50S ribosomal protein L23 & PF00276 & $\begin{array}{l}\text { IPR012677; IPR012678; } \\
\text { IPR013025 }\end{array}$ \\
\hline Q8PNS1 & rplB & XAC0975 & 50S ribosomal protein L2 & $\begin{array}{l}\text { PF00181; } \\
\text { PF03947 }\end{array}$ & $\begin{array}{l}\text { IPR012340; IPR022666; } \\
\text { IPR014722; IPR002171; } \\
\text { IPR005880; IPR022669; } \\
\text { IPR022671; IPR014726; } \\
\text { IPR008991 }\end{array}$ \\
\hline Q8NKY0 & rplV & XAC0977 & 50S ribosomal protein $\mathrm{L} 22$ & PF00237 & $\begin{array}{l}\text { IPR001063; IPR018260; } \\
\text { IPR036394; IPR005727 }\end{array}$ \\
\hline Q8PNR8 & rplP & XАC0979 & 50S ribosomal protein L16 & PF00252 & $\begin{array}{l}\text { IPR016180; IPR036920; } \\
\text { IPR000114; IPR020798 }\end{array}$ \\
\hline Q8NL02 & rplN & XAC0982 & 50S ribosomal protein L14 & PF00238 & $\begin{array}{l}\text { IPR036853; IPR000218; } \\
\text { IPR005745; IPR019972 }\end{array}$ \\
\hline Q8PNR4 & rplE & XAC0984 & 50S ribosomal protein L5 & $\begin{array}{l}\text { PF00281; } \\
\text { PF00673 }\end{array}$ & $\begin{array}{l}\text { IPR002132; IPR020930; } \\
\text { IPR031309; IPR020929; } \\
\text { IPR022803; IPR031310 }\end{array}$ \\
\hline Q8PNR3 & $\mathrm{rpsH}$ & XAC0986 & 30S ribosomal protein $\mathrm{S} 8$ & PF00410 & IPR000630; IPR035987 \\
\hline Q8PNR1 & rplR & XAC0988 & 50S ribosomal protein L18 & PF00861 & IPR005484; IPR004389 \\
\hline Q8PNR0 & $\mathrm{rpmD}$ & XAC0990 & 50S ribosomal protein L30 & PF00327 & $\begin{array}{l}\text { IPR036919; IPR005996; } \\
\text { IPR016082 }\end{array}$ \\
\hline Q8PNQ9 & $\mathrm{rplO}$ & XАC0991 & 50S ribosomal protein L15 & PF00828 & $\begin{array}{l}\text { IPR036227; IPR030878; } \\
\text { IPR005749; IPR001196; } \\
\text { IPR021131 }\end{array}$ \\
\hline Q8NKX3 & rpsM & XAC0993 & $30 \mathrm{~S}$ ribosomal protein $\mathrm{S} 13$ & PF00416 & $\begin{array}{l}\text { IPR027437; IPR001892; } \\
\text { IPR010979; IPR019980; } \\
\text { IPR018269 }\end{array}$ \\
\hline
\end{tabular}




\begin{tabular}{|c|c|c|c|c|c|}
\hline POAOYO & rpsD & XAC0995 & 30S ribosomal protein $\mathrm{S} 4$ & $\begin{array}{l}\text { PF00163; } \\
\text { PF01479 }\end{array}$ & $\begin{array}{l}\text { IPR022801; IPR001912; } \\
\text { IPR005709; IPR018079; } \\
\text { IPR002942; IPR036986 }\end{array}$ \\
\hline Q8PNQ7 & $\mathrm{rplQ}$ & ХАC0997 & 50S ribosomal protein L17 & PF01196 & IPR000456; IPR036373 \\
\hline Q8PNP2 & mopB & XAC1012 & Outer membrane protein & $\begin{array}{l}\text { PF13505; } \\
\text { PF00691 }\end{array}$ & $\begin{array}{l}\text { IPR011250; IPR027385; } \\
\text { IPR006664; IPR006665; } \\
\text { IPR036737; IPR028974 }\end{array}$ \\
\hline Q8PNJ7 & & XAC1062 & Uncharacterized protein & & \\
\hline Q8PNF8 & slp & XAC1113 & Outer membrane protein Slp & PF03843 & IPR004658 \\
\hline Q8PND0 & fyuA & XAC1143 & TonB-dependent receptor & $\begin{array}{l}\text { PF07715; } \\
\text { PF00593 }\end{array}$ & $\begin{array}{l}\text { IPR012910; IPR039423; } \\
\text { IPR000531; IPR036942 }\end{array}$ \\
\hline Q8PNB0 & & XAC1163 & Uncharacterized protein & & \\
\hline Q8PN49 & $\min E$ & XAC1224 & $\begin{array}{l}\text { Cell division topological specificity } \\
\text { factor }\end{array}$ & PF03776 & IPR005527; IPR036707 \\
\hline Q8PN43 & & XАC1230 & Uncharacterized protein & & IPR011256 \\
\hline Q8PN35 & & $\mathrm{XAC} 1238$ & $\begin{array}{l}\text { Endo/exonuclease/phosphatase } \\
\text { domain-containing protein }\end{array}$ & PF03372 & IPR036691; IPR005135 \\
\hline Q8PN33 & & $\mathrm{XAC} 1240$ & Uncharacterized protein & $\begin{array}{l}\text { PF13202; } \\
\text { PF13499 }\end{array}$ & $\begin{array}{l}\text { IPR011992; IPR018247; } \\
\text { IPR002048 }\end{array}$ \\
\hline Q8PN25 & rplU & XAC1248 & 50S ribosomal protein L21 & PF00829 & $\begin{array}{l}\text { IPR036164; IPR028909; } \\
\text { IPR001787; IPR018258 }\end{array}$ \\
\hline Q8PMV4 & mucD & XAC1321 & $\begin{array}{l}\text { Periplasmic serine endoprotease } \\
\text { DegP-like (EC 3.4.21.107) }\end{array}$ & PF13180 & $\begin{array}{l}\text { IPR001478; IPR036034; } \\
\text { IPR011782; IPR009003; } \\
\text { IPR001940 }\end{array}$ \\
\hline Q8PMV1 & & XAC1324 & Uncharacterized protein & PF16137 & IPR032314 \\
\hline Q8PMS7 & & XАC1349 & Serine protease & $\begin{array}{l}\text { PF03797; } \\
\text { PF12951; } \\
\text { PF00082 }\end{array}$ & $\begin{array}{l}\text { IPR005546; IPR036709; } \\
\text { IPR013425; IPR000209; } \\
\text { IPR036852; IPR023827; } \\
\text { IPR023828; IPR015500; } \\
\text { IPR034061 }\end{array}$ \\
\hline Q8PMP7 & & XАC1379 & Uncharacterized protein & PF10099 & IPR018764 \\
\hline Q8PMM9 & & XAC1397 & $\begin{array}{l}\text { Alginate_exp domain-containing } \\
\text { protein }\end{array}$ & PF13372 & IPR025388 \\
\hline Q8PML3 & oma & XAC1413 & $\begin{array}{l}\text { Outer membrane protein assembly } \\
\text { factor BamA }\end{array}$ & $\begin{array}{l}\text { PF01103; } \\
\text { PF07244 }\end{array}$ & $\begin{array}{l}\text { IPR000184; IPR010827; } \\
\text { IPR039910; IPR023707; } \\
\text { IPR034746 }\end{array}$ \\
\hline Q8PMJ3 & & XAC1434 & CASH domain-containing protein & PF13229 & $\begin{array}{l}\text { IPR039448; IPR006633; } \\
\text { IPR022441; IPR006626; } \\
\text { IPR012334; IPR011050 }\end{array}$ \\
\hline Q8PMJ2 & fhuA & XAC1435 & Iron receptor & $\begin{array}{l}\text { PF07715; } \\
\text { PF00593 }\end{array}$ & $\begin{array}{l}\text { IPR012910; IPR037066; } \\
\text { IPR039423; IPR00053; } \\
\text { IPR036942; IPR010917; } \\
\text { IPR010105 }\end{array}$ \\
\hline Q8PMH2 & dcp & XAC1456 & Peptidyl-dipeptidase & PF01432 & $\begin{array}{l}\text { IPR034005; IPR024077; } \\
\text { IPR001567 }\end{array}$ \\
\hline Q8PMG5 & & XAC1463 & Phospholipase A1 (EC 3.1.1.32) (EC & PF02253 & IPR003187; IPR036541 \\
\hline
\end{tabular}




\begin{tabular}{|c|c|c|c|c|c|}
\hline Q8PMG3 & pcp & XAC1466 & $\begin{array}{l}\text { Peptidoglycan-associated outer } \\
\text { membrane lipoprotein }\end{array}$ & PF05433 & IPR008816 \\
\hline Q8PMF0 & & XAC1479 & OmpA family protein & $\begin{array}{l}\text { PF13488; } \\
\text { PF00691 }\end{array}$ & $\begin{array}{l}\text { IPR039567; IPR006664; } \\
\text { IPR006665; IPR006690; } \\
\text { IPR036737 }\end{array}$ \\
\hline Q8PMD2 & & XАC1497 & Uncharacterized protein & & \\
\hline Q8PMB6 & smpA & XAC1516 & $\begin{array}{l}\text { Outer membrane protein assembly } \\
\text { factor BamE }\end{array}$ & PF04355 & $\begin{array}{l}\text { IPR026592; IPR037873; } \\
\text { IPR007450 }\end{array}$ \\
\hline Q8PM83 & btuE & XAC1549 & Glutathione peroxidase & PF00255 & $\begin{array}{l}\text { IPR000889; IPR029759; } \\
\text { IPR036249 }\end{array}$ \\
\hline Q8PM82 & fkpA & $\mathrm{XAC} 1550$ & $\begin{array}{l}\text { Peptidyl-prolyl cis-trans isomerase } \\
\text { (EC 5.2.1.8) }\end{array}$ & $\begin{array}{l}\text { PF00254; } \\
\text { PF01346 }\end{array}$ & $\begin{array}{l}\text { IPR001179; IPR000774; } \\
\text { IPR036944 }\end{array}$ \\
\hline Q8PM54 & oprO & XAC1579 & Polyphosphate-selective porin $\mathrm{O}$ & PF07396 & IPR023614; IPR010870 \\
\hline Q8NL26 & & XAC1585 & $\begin{array}{l}\text { Peptidyl-prolyl cis-trans isomerase } \\
\text { (EC 5.2.1.8) }\end{array}$ & $\begin{array}{l}\text { PF00254; } \\
\text { PF01346 }\end{array}$ & $\begin{array}{l}\text { IPR001179; IPR000774; } \\
\text { IPR036944 }\end{array}$ \\
\hline Q8PM13 & rpsR & XAC1621 & 30S ribosomal protein S18 & PF01084 & $\begin{array}{l}\text { IPR001648; IPR018275; } \\
\text { IPR036870 }\end{array}$ \\
\hline Q8PLS7 & & $\mathrm{XAC} 1712$ & DUF218 dc & PF02698 & IPR003848; IPR014729 \\
\hline Q8PLR1 & nlpD & XAC1728 & Lipoprotein & $\begin{array}{l}\text { PF01476; } \\
\text { PF01551 }\end{array}$ & $\begin{array}{l}\text { IPR011055; IPR018392; } \\
\text { IPR036779; IPR016047 }\end{array}$ \\
\hline Q8PLN4 & & XAC1761 & Uncharacterized protein & & \\
\hline Q8PL93 & cirA & XAC1910 & TonB-dependent receptor & $\begin{array}{l}\text { PF07715; } \\
\text { PF00593 }\end{array}$ & $\begin{array}{l}\text { IPR012910; IPR037066; } \\
\text { IPR000531; IPR010104 }\end{array}$ \\
\hline Q8PKZ8 & lolA & XAC2008 & $\begin{array}{l}\text { Outer-membrane lipoprotein carrier } \\
\text { protein }\end{array}$ & PF03548 & $\begin{array}{l}\text { IPR029046; IPR004564; } \\
\text { IPR018323 }\end{array}$ \\
\hline Q8PKZ0 & pilF & XAC2017 & Fimbrial biogenesis protein & & $\begin{array}{l}\text { IPR013360; IPR013026; } \\
\text { IPR011990; IPR019734 }\end{array}$ \\
\hline Q8PKY7 & bamB & XAC2020 & $\begin{array}{l}\text { Outer membrane protein assembly } \\
\text { factor BamB }\end{array}$ & PF13360 & $\begin{array}{l}\text { IPR017687; IPR018391; } \\
\text { IPR002372; IPR011047; } \\
\text { IPR015943 }\end{array}$ \\
\hline Q8PK64 & & XAC2312 & $\begin{array}{l}\text { TonB_dep_Rec domain-containing } \\
\text { protein }\end{array}$ & PF00593 & $\begin{array}{l}\text { IPR039426; IPR013784; } \\
\text { IPR000531 }\end{array}$ \\
\hline Q8PK57 & & XAC2319 & Uncharacterized protein & & \\
\hline Q8PK24 & & XAC2353 & Uncharacterized protein & & \\
\hline Q8PJM6 & $\operatorname{rpfN}$ & XAC2504 & Porin & PF04966 & IPR007049; IPR038673 \\
\hline Q8PJK8 & ggt & XAC2523 & Gamma-glutamyltranspeptidase & & $\begin{array}{l}\text { IPR043138; IPR000101; } \\
\text { IPR043137; IPR029055 }\end{array}$ \\
\hline Q8PJK6 & & XAC2525 & Uncharacterized protein & & \\
\hline Q8PJK0 & btuB & XAC2531 & TonB-dependent receptor & $\begin{array}{l}\text { PF07715; } \\
\text { PF00593 }\end{array}$ & $\begin{array}{l}\text { IPR012910; IPR037066; } \\
\text { IPR000531; IPR010916 }\end{array}$ \\
\hline Q8PJH0 & & XAC2562 & Uncha & & \\
\hline Q8PJE3 & rplT & XAC2591 & $50 \mathrm{~S}$ ribosomal protein $\mathrm{L} 20$ & PF00453 & IPR005813; IPR035566 \\
\hline Q8PJD5 & btuB & XAC2600 & TonB-dependent receptor & PF07715 & $\begin{array}{l}\text { IPR012910; IPR037066; } \\
\text { IPR010104; IPR010917 }\end{array}$ \\
\hline
\end{tabular}




\begin{tabular}{|c|c|c|c|c|c|}
\hline Q8PJC4 & & XAC2611 & DUF4189 domain-containing protein & PF13827 & IPR025240 \\
\hline Q8PJB5 & virB9 & XAC2620 & VirB9 protein & PF03524 & $\begin{array}{l}\text { IPR010258; IPR033645; } \\
\text { IPR038161 }\end{array}$ \\
\hline Q8PJ70 & oar & XAC2672 & Oar protein & & $\begin{array}{l}\text { IPR039426; IPR008969; } \\
\text { IPR036942 }\end{array}$ \\
\hline Q8PJ58 & $\mathrm{rpsO}$ & XAC2684 & 30S ribosomal protein S15 & PF00312 & $\begin{array}{l}\text { IPR000589; IPR005290; } \\
\text { IPR009068 }\end{array}$ \\
\hline Q8PJ03 & btuB & XAC2742 & TonB-dependent receptor & $\begin{array}{l}\text { PF07715; } \\
\text { PF00593 }\end{array}$ & $\begin{array}{l}\text { IPR012910; IPR037066; } \\
\text { IPR000531; IPR010917 }\end{array}$ \\
\hline Q8PJ02 & oar & XAC2743 & Oar protein & $\begin{array}{l}\text { PF07715; } \\
\text { PF00593 }\end{array}$ & $\begin{array}{l}\text { IPR039426; IPR013784; } \\
\text { IPR012910; IPR037066; } \\
\text { IPR000531 }\end{array}$ \\
\hline Q8PIY6 & phoA & XАC2759 & Alkaline phosphatase & PF00245 & IPR001952; IPR017850 \\
\hline Q8PIX3 & bp26 & XAC2772 & Outer membrane protein & PF04402 & IPR007497 \\
\hline Q8PIX2 & oar & XAC2773 & Oar protein & $\begin{array}{l}\text { PF07715; } \\
\text { PF00593 }\end{array}$ & $\begin{array}{l}\text { IPR039426; IPR013784; } \\
\text { IPR012910; IPR037066; } \\
\text { IPR000531 }\end{array}$ \\
\hline Q8PIW5 & rlpB & XAC2780 & LPS-assembly lipoprotein LptE & PF04390 & IPR007485 \\
\hline Q8PIU4 & & XАC2801 & Uncharacterized protein & PF06629 & IPR010583 \\
\hline Q8PIR6 & phuR & XAC2829 & Outer membrane hemin & $\begin{array}{l}\text { PF07715; } \\
\text { PF00593 }\end{array}$ & $\begin{array}{l}\text { IPR039426; IPR012910; } \\
\text { IPR037066; IPR000531; } \\
\text { IPR036942 }\end{array}$ \\
\hline Q8PIF7 & fhuA & XAC2941 & TonB-dependent receptor & $\begin{array}{l}\text { PF07715; } \\
\text { PF00593 }\end{array}$ & $\begin{array}{l}\text { IPR012910; IPR037066; } \\
\text { IPR039423; IPR000531; } \\
\text { IPR036942; IPR010105 }\end{array}$ \\
\hline Q8PIF2 & & XАC2946 & Uncharacterized protein & PF10670 & IPR019613 \\
\hline Q8PIE7 & comEA & XАC2951 & DNA transport competence protein & & IPR004509; IPR010994 \\
\hline Q8PIE0 & & XAC2958 & Uncharacterized protein & PF09839 & IPR018642 \\
\hline Q8PID5 & & XАC2963 & Uncharacterized protein & PF11306 & IPR021457 \\
\hline Q8PI48 & btuB & XAC3050 & TonB-dependent receptor & $\begin{array}{l}\text { PF07715; } \\
\text { PF00593 }\end{array}$ & $\begin{array}{l}\text { IPR012910; IPR037066; } \\
\text { IPR000531; IPR036942 }\end{array}$ \\
\hline Q8PI41 & bla & XАC3057 & Beta-lactamase & PF00144 & IPR001466; IPR012338 \\
\hline Q8PI27 & iroN & XАC3071 & TonB-dependent receptor & $\begin{array}{l}\text { PF07715; } \\
\text { PF00593 }\end{array}$ & $\begin{array}{l}\text { IPR012910; IPR037066; } \\
\text { IPR000531; IPR010104 }\end{array}$ \\
\hline Q8PHZ0 & & XAC3108 & Uncharacterized protein & & IPR011990 \\
\hline Q8PHV9 & cpoB & XAC3140 & Cell division coordinator $\mathrm{CpoB}$ & $\begin{array}{l}\text { PF16331; } \\
\text { PF13525 }\end{array}$ & $\begin{array}{l}\text { IPR039565; IPR034706; } \\
\text { IPR014162; IPR013026; } \\
\text { IPR011990; IPR019734; } \\
\text { IPR032519 }\end{array}$ \\
\hline Q8PHV8 & ompP6 & XAC3141 & Peptidoglycan-associated protein & PF00691 & $\begin{array}{l}\text { IPR006664; IPR006665; } \\
\text { IPR036737; IPR039001; } \\
\text { IPR014169 }\end{array}$ \\
\hline Q8PHV7 & tolB & XAC3142 & Tol-Pal system protein TolB & $\begin{array}{l}\text { PF07676; } \\
\text { PF04052 }\end{array}$ & $\begin{array}{l}\text { IPR011042; IPR011659; } \\
\text { IPR014167; IPR007195; } \\
\text { IPR036752 }\end{array}$ \\
\hline Q8PHV5 & tolR & XAC3144 & Tol-Pal system protein TolR & PF02472 & IPR003400; IPR014168 \\
\hline
\end{tabular}




\begin{tabular}{|c|c|c|c|c|c|}
\hline Q8PHV4 & tolQ & XAC3145 & Tol-Pal system protein TolQ & PF01618 & IPR002898; IPR014163 \\
\hline Q8PHU4 & & XAC3155 & Uncharacterized protein & PF11218 & IPR021381 \\
\hline Q8PHT7 & bla & XAC3162 & Beta-lactamase (EC 3.5.2.6) & & $\begin{array}{l}\text { IPR012338; IPR000871; } \\
\text { IPR023650; IPR006311 }\end{array}$ \\
\hline Q8PHT1 & bfeA & XAC3168 & Ferric enterobactin receptor & $\begin{array}{l}\text { PF07715; } \\
\text { PF00593 }\end{array}$ & $\begin{array}{l}\text { IPR012910; IPR037066; } \\
\text { IPR000531; IPR010916; } \\
\text { IPR036942 }\end{array}$ \\
\hline Q8PHT0 & bfeA & XAC3169 & Ferric enterobactin receptor & $\begin{array}{l}\text { PF07715; } \\
\text { PF00593 }\end{array}$ & $\begin{array}{l}\text { IPR012910; IPR037066; } \\
\text { IPR000531; IPR036942 }\end{array}$ \\
\hline Q8PHS3 & fecA & XAC3176 & Citrate-dependent iron transporter & $\begin{array}{l}\text { PF07715; } \\
\text { PF00593 }\end{array}$ & $\begin{array}{l}\text { IPR012910; IPR037066; } \\
\text { IPR000531; IPR036942; } \\
\text { IPR010105 }\end{array}$ \\
\hline Q8PHQ5 & btuB & XAC3194 & $\begin{array}{l}\text { Outer membrane receptor for transport } \\
\text { of vitamin B }\end{array}$ & $\begin{array}{l}\text { PF07715; } \\
\text { PF00593 }\end{array}$ & $\begin{array}{l}\text { IPR010101; IPR039426; } \\
\text { IPR012910; IPR037066; } \\
\text { IPR000531; IPR036942 }\end{array}$ \\
\hline Q8PHP1 & bfeA & XAC3207 & Ferric enterobactin receptor & $\begin{array}{l}\text { PF07715; } \\
\text { PF00593 }\end{array}$ & $\begin{array}{l}\text { IPR012910; IPR037066; } \\
\text { IPR000531; IPR010916; } \\
\text { IPR036942 }\end{array}$ \\
\hline Q8PHN1 & comL & XAC3218 & $\begin{array}{l}\text { Outer membrane protein assembly } \\
\text { factor BamD }\end{array}$ & PF13525 & $\begin{array}{l}\text { IPR017689; IPR039565; } \\
\text { IPR013026; IPR011990 }\end{array}$ \\
\hline Q8PHL0 & fimA & XAC3241 & Fimbrillin & $\begin{array}{l}\text { PF07963; } \\
\text { PF00114 }\end{array}$ & IPR012902; IPR001082 \\
\hline Q8PHF7 & estA & XAC3300 & Lipase & $\begin{array}{l}\text { PF03797; } \\
\text { PF00657 }\end{array}$ & $\begin{array}{l}\text { IPR005546; IPR036709; } \\
\text { IPR001087; IPR017186; } \\
\text { IPR036514 }\end{array}$ \\
\hline Q8PHE6 & iroN & XAC3311 & TonB-dependent receptor & $\begin{array}{l}\text { PF07715; } \\
\text { PF00593 }\end{array}$ & $\begin{array}{l}\text { IPR012910; IPR037066; } \\
\text { IPR006311; IPR000531; } \\
\text { IPR036942; IPR010104 }\end{array}$ \\
\hline Q8PHC5 & fecA & XAC3334 & TonB-dependent receptor & $\begin{array}{l}\text { PF07715; } \\
\text { PF00593 }\end{array}$ & $\begin{array}{l}\text { IPR039426; IPR012910; } \\
\text { IPR037066; IPR000531; } \\
\text { IPR036942 }\end{array}$ \\
\hline Q8PHA8 & & XAC3351 & Uncharacterized protein & & \\
\hline Q8PHA5 & ompW & XAC3354 & Outer membrane protein $\mathrm{W}$ & PF03922 & IPR011250; IPR005618 \\
\hline Q8PHA4 & omp21 & XAC3355 & Outer membrane protein & PF03922 & IPR011250; IPR005618 \\
\hline Q8PH89 & fhuE & XAC3370 & $\begin{array}{l}\text { Outer membrane receptor for ferric } \\
\text { iron uptake }\end{array}$ & $\begin{array}{l}\text { PF07715; } \\
\text { PF00593 }\end{array}$ & $\begin{array}{l}\text { IPR012910; IPR037066; } \\
\text { IPR039423; IPR000531; } \\
\text { IPR036942; IPR010105 }\end{array}$ \\
\hline Q8PH16 & btuB & XАC3444 & TonB-dependent receptor & $\begin{array}{l}\text { PF07715; } \\
\text { PF00593 }\end{array}$ & $\begin{array}{l}\text { IPR012910; IPR037066; } \\
\text { IPR000531; IPR036942 }\end{array}$ \\
\hline Q8PGZ9 & tolC & XAC3463 & TolC protein & PF02321 & IPR003423; IPR010130 \\
\hline Q8PGZ0 & oprO & XAC3472 & Polyphosphate-selective porin $\mathrm{O}$ & PF07396 & IPR023614; IPR010870 \\
\hline Q8PGX3 & fyuA & XAC3489 & TonB-dependent receptor & $\begin{array}{l}\text { PF07715; } \\
\text { PF00593 }\end{array}$ & $\begin{array}{l}\text { IPR012910; IPR037066; } \\
\text { IPR039423; IPR000531; } \\
\text { IPR036942 }\end{array}$ \\
\hline Q8PGW4 & fhuE & XAC3498 & $\begin{array}{l}\text { Outer membrane receptor for ferric } \\
\text { iron uptake }\end{array}$ & $\begin{array}{l}\text { PF07715; } \\
\text { PF00593 }\end{array}$ & $\begin{array}{l}\text { IPR012910; IPR037066; } \\
\text { IPR039423; IPR000531; }\end{array}$ \\
\hline
\end{tabular}




\begin{tabular}{|c|c|c|c|c|c|}
\hline Q8PGU1 & & XAC3525 & Uncharacterized protein & & \\
\hline Q8PGL1 & uptE & XAC3605 & Outer membrane protein & & IPR036737 \\
\hline Q8PGLO & uptD & XAC3606 & Outer membran protein & PF14346 & IPR025511 \\
\hline Q8PGJ6 & pfeA & XАC3620 & Siderophore receptor protein & $\begin{array}{l}\text { PF07715; } \\
\text { PF00593 }\end{array}$ & $\begin{array}{l}\text { IPR039426; IPR012910; } \\
\text { IPR037066; IPR000531; } \\
\text { IPR036942; IPR010917; } \\
\text { IPR010105 }\end{array}$ \\
\hline Q8PGG6 & atpG & XАC3650 & $\begin{array}{l}\text { ATP synthase gamma chain (ATP } \\
\text { synthase F1 sector gamma subunit) }\end{array}$ & PF00231 & $\begin{array}{l}\text { IPR035968; IPR000131; } \\
\text { IPR023632 }\end{array}$ \\
\hline Q8PGG0 & & XAC3657 & Uncharacterized protein & & IPR011250 \\
\hline Q8PGF7 & & XAC3660 & Uncharacterized protein & & \\
\hline Q8PGF3 & ompW & XAC3664 & Outer membrane protein & PF03922 & IPR011250; IPR005618 \\
\hline Q8PGF0 & & XAC3667 & Lipoprotein & PF03180 & IPR004872 \\
\hline Q8PGC9 & dadA & XAC3688 & $\begin{array}{l}\text { D-amino acid dehydrogenase (EC } \\
\text { 1.4.99.-) }\end{array}$ & PF01266 & $\begin{array}{l}\text { IPR023080; IPR006076; } \\
\text { IPR036188 }\end{array}$ \\
\hline Q8PFX5 & amaA & XAC3847 & N-acyl-L-amino acid amidohydrolase & $\begin{array}{l}\text { PF07687; } \\
\text { PF01546 }\end{array}$ & $\begin{array}{l}\text { IPR017439; IPR036264; } \\
\text { IPR002933; IPR011650 }\end{array}$ \\
\hline Q8PFW2 & & XAC3860 & $\mathrm{N}$-acetylmuramoyl-L-alanine amidase & PF01510 & IPR036505; IPR002502 \\
\hline Q8PFV4 & yliI & XАC3868 & Dehydrogenase & PF07995 & $\begin{array}{l}\text { IPR011042; IPR012938; } \\
\text { IPR011041 }\end{array}$ \\
\hline P66535 & $\operatorname{rps} U$ & XАC3872 & otein S21 & PF01165 & $\begin{array}{l}\text { IPR001911; IPR018278; } \\
\text { IPR038380 }\end{array}$ \\
\hline Q8PFR1 & & XAC3917 & SPOR domain-containing protein & PF05036 & IPR007730; IPR036680 \\
\hline Q8PFQ2 & & XАC3926 & OMP_b-brl domain-containing protein & PF13505 & IPR011250; IPR027385 \\
\hline Q8PFK1 & htrA & XAC3980 & $\begin{array}{l}\text { Periplasmic serine endoprotease } \\
\text { DegP-like (EC 3.4.21.107) }\end{array}$ & PF13180 & $\begin{array}{l}\text { IPR001478; IPR036034; } \\
\text { IPR011782; IPR009003; } \\
\text { IPR001940 }\end{array}$ \\
\hline Q8PFK0 & & XАC3981 & Uncharacterized protein & & \\
\hline Q8PFH3 & ecnA & XAC4008 & Entericidin A & PF08085 & IPR012556 \\
\hline Q8PFD5 & iroN & XАC4048 & TonB-dependent receptor & $\begin{array}{l}\text { PF07715; } \\
\text { PF00593 }\end{array}$ & $\begin{array}{l}\text { IPR012910; IPR037066; } \\
\text { IPR000531; IPR010104 }\end{array}$ \\
\hline P66160 & rpmB & XAC4159 & $50 \mathrm{~S}$ ribosomal protein $\mathrm{L} 28$ & PF00830 & $\begin{array}{l}\text { IPR034704; IPR026569; } \\
\text { IPR037147; IPR001383 }\end{array}$ \\
\hline Q8PEX1 & & XАC4219 & Ysc84 domain-containing protein & PF04366 & IPR007461 \\
\hline Q8PER7 & & XAC4273 & OmpA-related protein & PF00593 & $\begin{array}{l}\text { IPR039426; IPR013784; } \\
\text { IPR000531 }\end{array}$ \\
\hline Q8PER6 & & XAC4274 & OmpA-related protein & PF00593 & $\begin{array}{l}\text { IPR039426; IPR013784; } \\
\text { IPR000531 }\end{array}$ \\
\hline Q8PEK7 & yrbC & XAC4342 & Toluene tolerance protein & PF05494 & IPR008869; IPR042245 \\
\hline Q8PEK5 & vacJ & XАC4344 & Lipoprotein & PF04333 & IPR007428 \\
\hline Q8PRJ3 & virB9 & XACb0039 & VirB9 protein & PF03524 & $\begin{array}{l}\text { IPR010258; IPR014148; } \\
\text { IPR033645; IPR038161 }\end{array}$ \\
\hline Q8NL05 & $\operatorname{rpsN}$ & & 30S ribosomal protein $\mathrm{S} 14$ & PF00253 & $\begin{array}{l}\text { IPR001209; IPR043140; } \\
\text { IPR023036 }\end{array}$ \\
\hline
\end{tabular}


Table S2. Results from the TQ ICP-MS elemental analysis of samples containing

846 purified OMV suspended in PBS. The data for Fig. 6B were obtained by subtracting the

847 background concentration of each element in PBS and normalizing the values for each sample

848 based on their respective carbon content. See also Table S3 and Table S4 for experimental

849 details. LOD: limit of detection.

\begin{tabular}{|c|c|c|c|c|c|c|c|c|c|c|c|c|c|}
\hline \multirow{2}{*}{$\frac{\text { Element }}{\mathrm{C}}$} & \multicolumn{2}{|c|}{ Buffer PBS 1x } & \multicolumn{3}{|c|}{ Sample 1} & \multicolumn{3}{|c|}{ Sample 2} & \multicolumn{3}{|c|}{ Sample 3} & \multirow{2}{*}{$\begin{array}{c}\text { LOD } \\
24.8\end{array}$} & \multirow{2}{*}{$\frac{\text { Unit }}{\mathrm{mg} \mathrm{L}^{-1}}$} \\
\hline & & LOD & 776 & \pm & 13 & 1285 & \pm & 3 & 899 & \pm & 2 & & \\
\hline $\mathrm{Mg}$ & \multicolumn{2}{|c|}{$<\mathrm{LOD}$} & 41.4 & \pm & 0.6 & 80.6 & \pm & 1.0 & 51.2 & \pm & 1.0 & 0.295 & $\mu \mathrm{g} \mathrm{L}^{-1}$ \\
\hline $\mathrm{S}$ & 80 & \pm & 112 & \pm & 2 & 152 & \pm & 3 & 113 & \pm & 2 & 0.473 & $\mu \mathrm{g} \mathrm{L}^{-1}$ \\
\hline $\mathrm{Ca}$ & 47 & \pm & 273 & \pm & 3 & 292 & \pm & 10 & 232 & \pm & 6 & 6.782 & $\mu \mathrm{g} \mathrm{L}^{-1}$ \\
\hline $\mathrm{Mn}$ & 0.09 & 0.01 & 0.43 & \pm & 0.01 & 0.62 & \pm & 0.03 & 0.54 & \pm & 0.01 & 0.007 & $\mu g \mathrm{~L}^{-1}$ \\
\hline $\mathrm{Fe}$ & 1.58 & 0.14 & 2.13 & \pm & 0.03 & 2.32 & \pm & 0.10 & 2.85 & \pm & 0.14 & 0.196 & $\mu \mathrm{g} \mathrm{L}^{-1}$ \\
\hline Co & 0.044 & $\pm \quad 0.003$ & 0.053 & \pm & 0.005 & 0.052 & \pm & 0.003 & 0.059 & \pm & 0.006 & 0.001 & $\mu \mathrm{g} \mathrm{L}^{-1}$ \\
\hline $\mathrm{Ni}$ & 0.48 & 0.02 & 3.08 & \pm & 0.09 & 0.96 & \pm & 0.06 & 0.97 & \pm & 0.10 & 0.154 & $\mu \mathrm{g} \mathrm{L}^{-1}$ \\
\hline $\mathrm{Cu}$ & \multicolumn{2}{|c|}{$<\mathrm{LOD}$} & 0.132 & \pm & 0.002 & \multicolumn{3}{|c|}{$<\mathrm{LOD}$} & \multicolumn{3}{|c|}{$<$ LOD } & 0.037 & $\mu \mathrm{g} \mathrm{L}^{-1}$ \\
\hline $\mathrm{Zn}$ & 1.06 & 0.03 & 6.97 & \pm & 0.10 & 8.04 & \pm & 0.15 & 14.57 & \pm & 0.12 & 0.175 & $\mu \mathrm{g} \mathrm{L}^{-1}$ \\
\hline $\mathrm{Br}$ & 153 & \pm & 136 & \pm & 14 & 149 & \pm & 11 & 138 & \pm & 7 & 0.042 & $\mu \mathrm{g} \mathrm{L}^{-1}$ \\
\hline $\mathrm{Se}$ & \multicolumn{2}{|c|}{$<$ LOD } & \multicolumn{3}{|c|}{$<$ LOD } & 0.004 & \pm & 0.001 & \multicolumn{3}{|c|}{$<\mathrm{LOD}$} & 0.002 & $\mu \mathrm{g} \mathrm{L}^{-1}$ \\
\hline $\mathrm{Ba}$ & 1.01 & 0.03 & 1.15 & \pm & 0.01 & 1.49 & \pm & 0.02 & 1.27 & \pm & 0.02 & 0.003 & $\mu \mathrm{g} \mathrm{L}^{-1}$ \\
\hline
\end{tabular}


851 Table S3. Mass values defined in the quadrupoles for the TQ ICP-MS elemental analysis.

\begin{tabular}{|c|c|c|c|c|c|c|c|c|c|c|}
\hline Element & Isotope & $\begin{array}{l}\text { Analysis } \\
\text { Mode }\end{array}$ & $\begin{array}{c}\mathbf{Q}_{1} \\
\text { mass }\end{array}$ & $\begin{array}{c}\mathbf{Q}_{2} \\
\text { filled } \\
\text { with }\end{array}$ & $\mathbf{Q}_{3}$ mass & LOD & Unit & $\begin{array}{l}\text { Linear } \\
\text { Range }\end{array}$ & $\begin{array}{l}\text { Sensitivity } \\
\left(\operatorname{cps} \mathrm{L} \mu \mathrm{g}^{-1}\right)\end{array}$ & $\mathbf{R}^{2}$ \\
\hline $\mathrm{C}$ & 12 & $\begin{array}{l}\text { SQ - } \\
\text { KED }\end{array}$ & --- & Helium & 12 & 24.8 & $\operatorname{mg~} L^{-1}$ & $50-1500$ & $3.0 \times 10^{2}$ & 0.9999 \\
\hline $\mathrm{Mg}$ & 24 & $\begin{array}{l}\text { SQ - } \\
\text { KED }\end{array}$ & --- & Helium & 24 & 0.295 & $\mu \mathrm{g} \mathrm{L}^{-1}$ & $25-100$ & $6.3 \times 10^{2}$ & 0.9924 \\
\hline S & 32 & TQ - O2 & 32 & Oxygen & $\begin{array}{c}48 \\
\left({ }^{32} \mathrm{~S} .{ }^{16} \mathrm{O}^{+}\right)\end{array}$ & 0.473 & $\mu \mathrm{g} \mathrm{L}^{-1}$ & $3-160$ & $1.9 \times 10^{3}$ & 0.9987 \\
\hline $\mathrm{Ca}$ & 44 & $\begin{array}{l}\mathrm{SQ}- \\
\mathrm{KED}\end{array}$ & --- & Helium & 44 & 6.782 & $\mu \mathrm{g} \mathrm{L}^{-1}$ & $25-500$ & $4.5 \times 10^{1}$ & 0.9997 \\
\hline $\mathrm{Mn}$ & 55 & $\begin{array}{l}\text { SQ - } \\
\text { KED }\end{array}$ & --- & Helium & 55 & 0.007 & $\mu g \mathrm{~L}^{-1}$ & $0.01-5$ & $9.2 \times 10^{3}$ & 0.9999 \\
\hline $\mathrm{Fe}$ & 57 & $\begin{array}{l}\text { SQ - } \\
\text { KED }\end{array}$ & --- & Helium & 57 & 0.196 & $\mu \mathrm{g} \mathrm{L}^{-1}$ & $0.25-5$ & $4.1 \times 10^{2}$ & 0.9977 \\
\hline Co & 59 & $\begin{array}{l}\text { SQ - } \\
\text { KED }\end{array}$ & --- & Helium & 59 & 0.001 & $\mu \mathrm{g} \mathrm{L}^{-1}$ & $0.01-1$ & $3.8 \times 10^{4}$ & 0.9993 \\
\hline $\mathrm{Ni}$ & 60 & $\begin{array}{l}\text { SQ - } \\
\text { KED }\end{array}$ & --- & Helium & 60 & 0.154 & $\mu \mathrm{g} \mathrm{L}^{-1}$ & $0.25-10$ & $1.2 \times 10^{4}$ & 0.9939 \\
\hline $\mathrm{Cu}$ & 63 & $\begin{array}{l}\text { SQ - } \\
\text { KED }\end{array}$ & --- & Helium & 63 & 0.037 & $\mu g \mathrm{~L}^{-1}$ & $0.05-10$ & $3.1 \times 10^{4}$ & 0.9999 \\
\hline $\mathrm{Zn}$ & 66 & $\begin{array}{l}\text { SQ - } \\
\text { KED }\end{array}$ & --- & Helium & 66 & 0.175 & $\mu \mathrm{g} \mathrm{L}^{-1}$ & $0.25-25$ & $4.1 \times 10^{3}$ & 0.9997 \\
\hline $\mathrm{Br}$ & 79 & TQ - O2 & 79 & Oxygen & $\begin{array}{c}95 \\
\left({ }^{79} \mathrm{Br} \cdot{ }^{16} \mathrm{O}^{+}\right)\end{array}$ & 0.042 & $\mu \mathrm{g} \mathrm{L}^{-1}$ & $50-500$ & $3.6 \times 10^{2}$ & 0.9999 \\
\hline $\mathrm{Se}$ & 80 & TQ - O2 & 80 & Oxygen & $\left({ }^{80} \mathrm{Se}^{96}{ }^{16} \mathrm{O}^{+}\right)$ & 0.002 & $\mu \mathrm{g} \mathrm{L}^{-1}$ & $0.005-1$ & $2.1 \times 10^{3}$ & 0.9993 \\
\hline $\mathrm{Ba}$ & 138 & TQ - O2 & 138 & Oxygen & $\begin{array}{c}154 \\
\left({ }^{138} \mathrm{Ba}^{16} \mathrm{O}^{+}\right) \\
\end{array}$ & 0.003 & $\mu \mathrm{g} \mathrm{L}^{-1}$ & $0.05-5$ & $5.2 \times 10^{4}$ & 0.9999 \\
\hline
\end{tabular}

852 
Table S4. TQ ICP-MS operating conditions.

\begin{tabular}{|c|c|}
\hline RF Power (W) & 1550 \\
\hline Argon coolant gas flow $\left(\mathrm{L} \min ^{-1}\right)$ & 14 \\
\hline Argon auxiliary gas flow $\left(L \mathrm{~min}^{-1}\right)$ & 0.8 \\
\hline Argon nebulizer flow $\left(\mathrm{L} \mathrm{min}^{-1}\right)$ & 1.04 \\
\hline He flow gas $\left(\mathrm{mL} \min ^{-1}\right)$ & 6.57 \\
\hline $\mathrm{O}_{2}$ flow gas $\left(\mathrm{mL} \mathrm{min}^{-1}\right)$ & 0.6 \\
\hline Nebulizer & MicroMist U-Series $0.4 \mathrm{~mL} \mathrm{~min}^{-1}$ \\
\hline Spray Chamber & Glass Cyclonic spray chamber \\
\hline Peristaltic Pump (rpm) & 40 \\
\hline Spray chamber temperature $\left({ }^{\circ} \mathrm{C}\right)$ & 2.7 \\
\hline Dwell time (s) & 0.1 \\
\hline Number of Sweeps & 10 \\
\hline
\end{tabular}


bioRxiv preprint doi: https://doi.org/10.1101/2021.04.26.441564; this version posted April 28, 2021. The copyright holder for this preprint (which was not certified by peer review) is the author/funder, who has granted bioRxiv a license to display the preprint in perpetuity. It is made available under aCC-BY-NC 4.0 International license.

\section{SB broth}

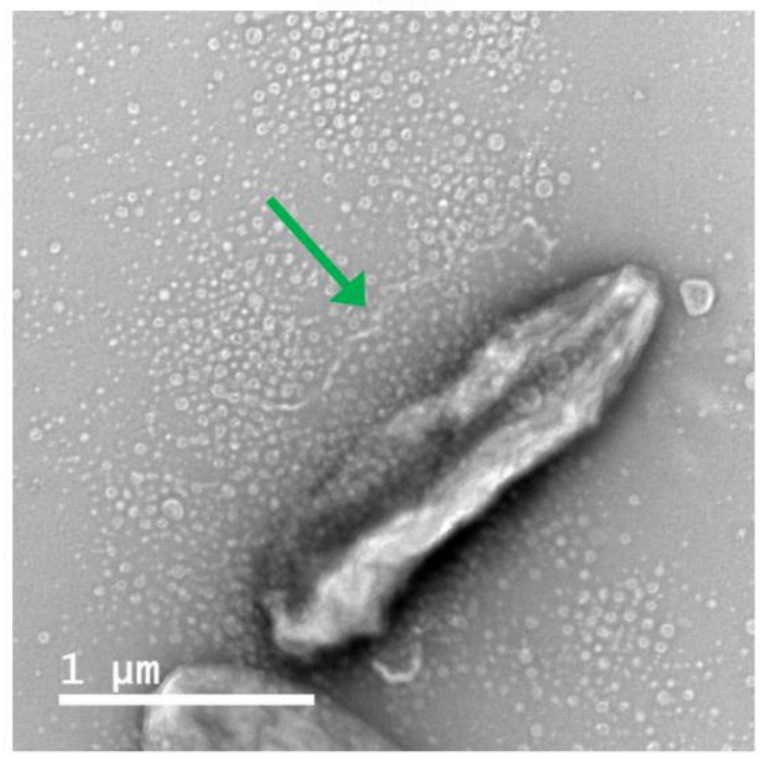

\section{LB $0.6 \%$ agar}

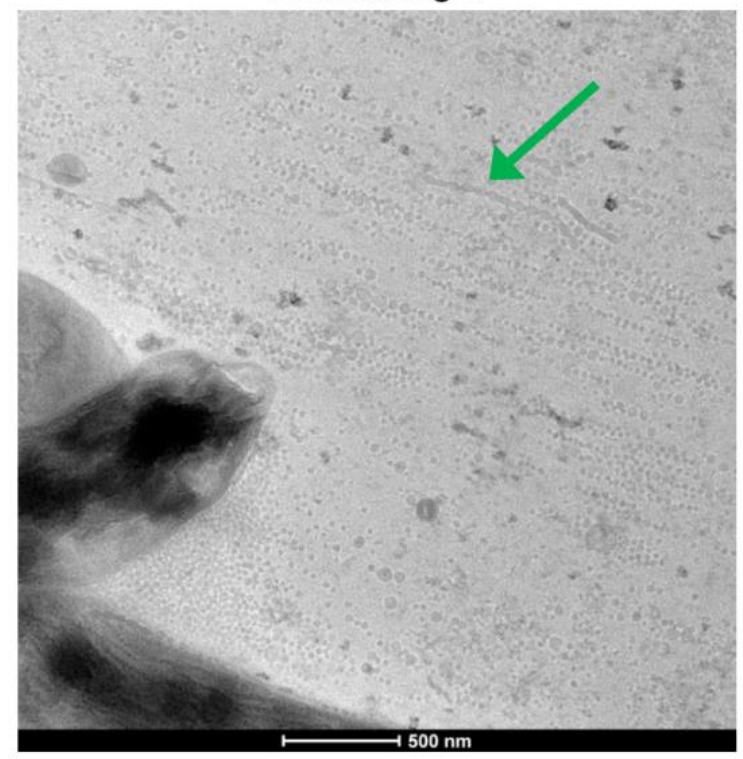

XVM2 0.6\% agar

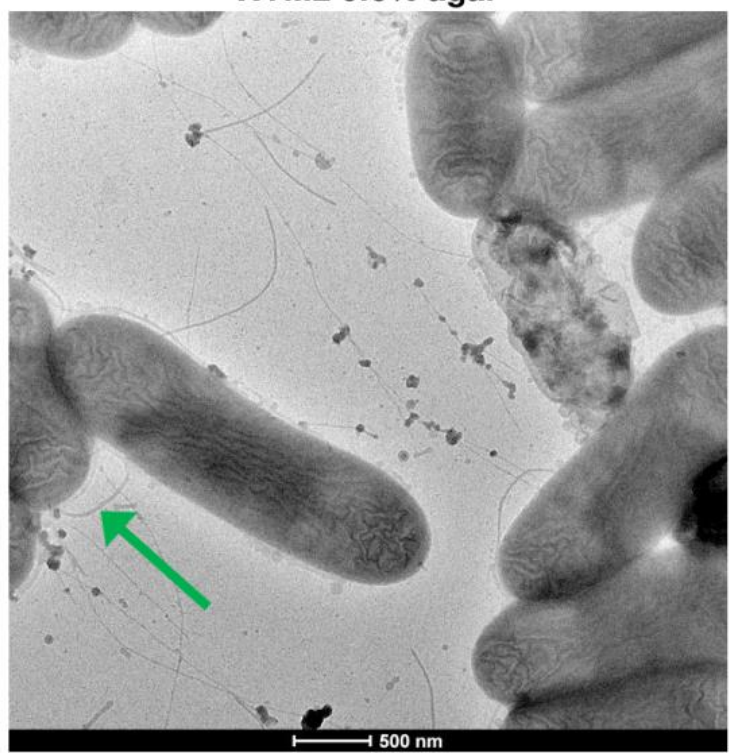

SB $1.5 \%$ agar

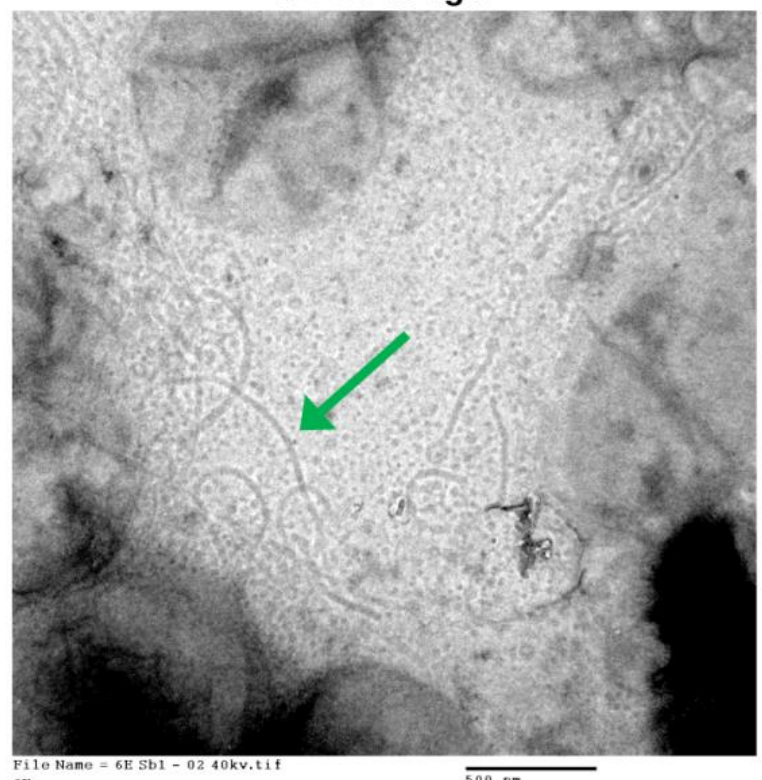

STON $0.6 \%$ agar

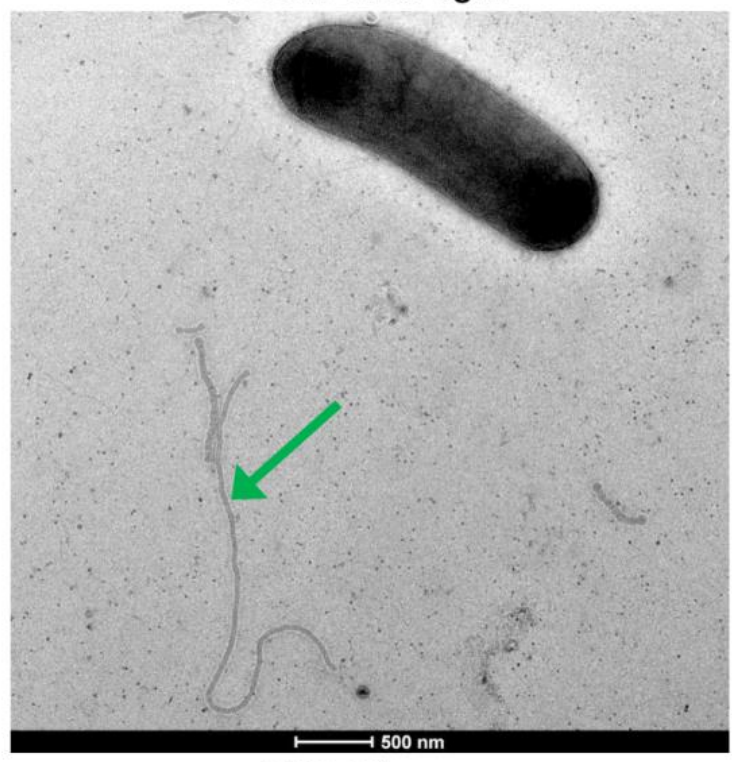

M9 $0.6 \%$ agar

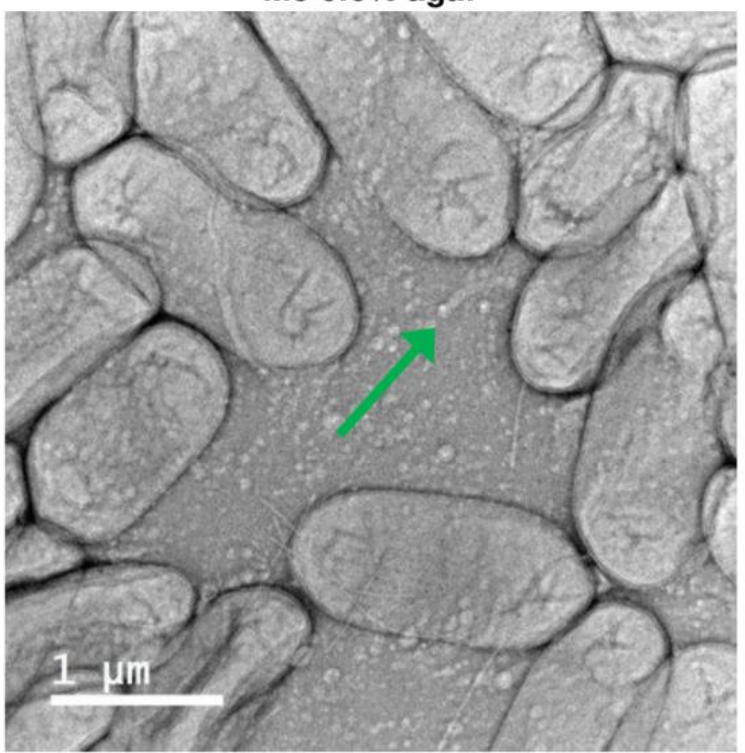


Fig. S1. Formation of outer membrane tubes by $X$. citri cells in different culture

858 conditions and media. The tested media include liquid SB, in which the samples were

859 concentrated by ultracentrifugation before being applied to the TEM grids, SB with 1.5\% agar (a

860 higher concentration than the $0.6 \%$ used for Fig. 1), LB with $0.6 \%$ agar, STON with $0.6 \%$ agar

861 (Guzzo et al., J Mol Biol, 2009, 10.1016/j.jmb.2009.07.065), XVM2 with 0.6\% agar (Wengelnik

862 et al., J Bacteriol, 1996, 10.1128/jb.178.4.1061-1069.1996), and M9 with 0.6\% agar. The green

863 arrows point to examples of the outer membrane tubes that can be seen in the images. 


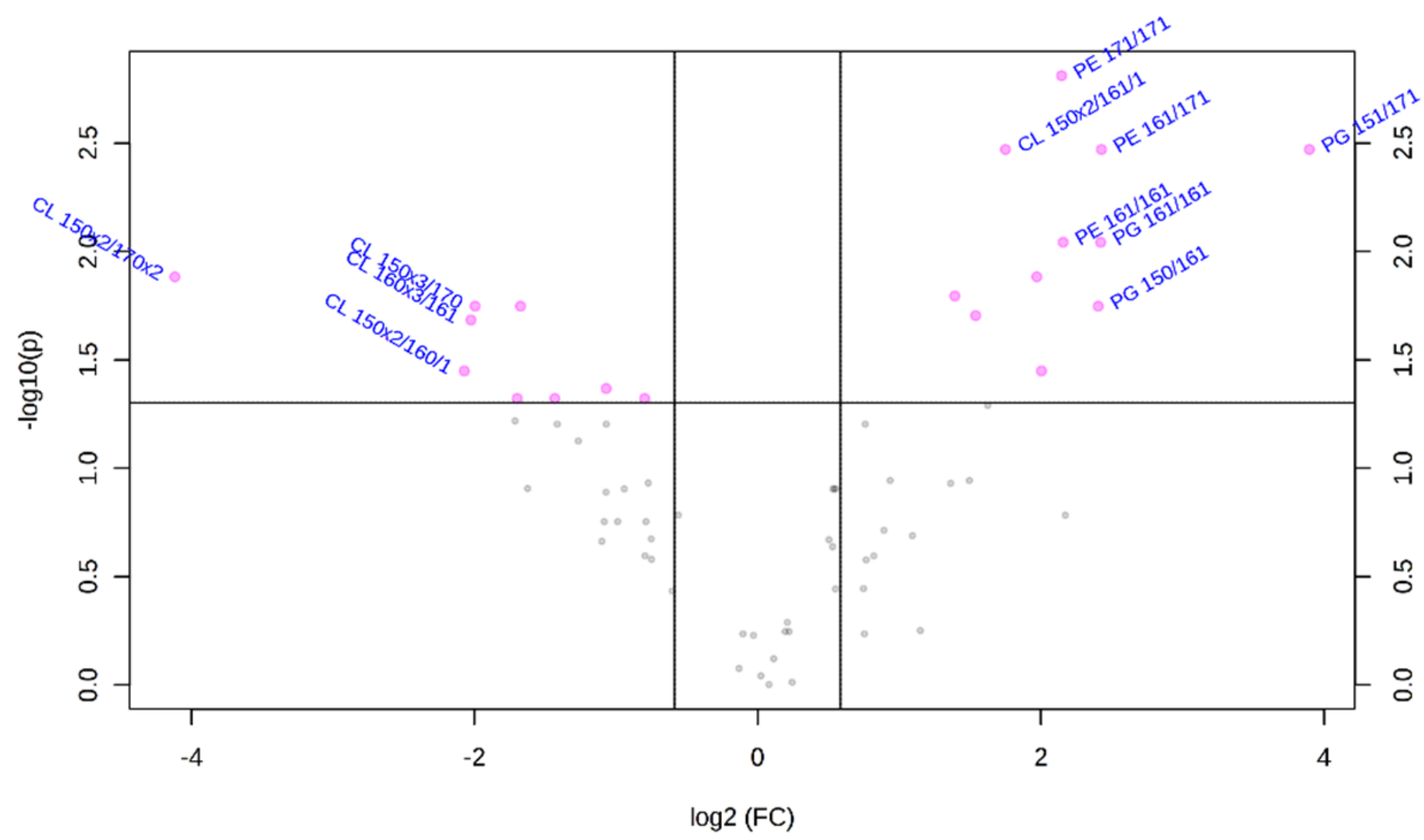

Fig. S2. Volcano plot analysis of the lipidomic data. The 20 most altered lipids between

867 the OMV and whole cell samples are identified in the plot as the ones presenting fold change

868 values above 1.5 and $\mathrm{p}<0.05$. Statistical significance was evaluated by FDR-adjusted t-test. 


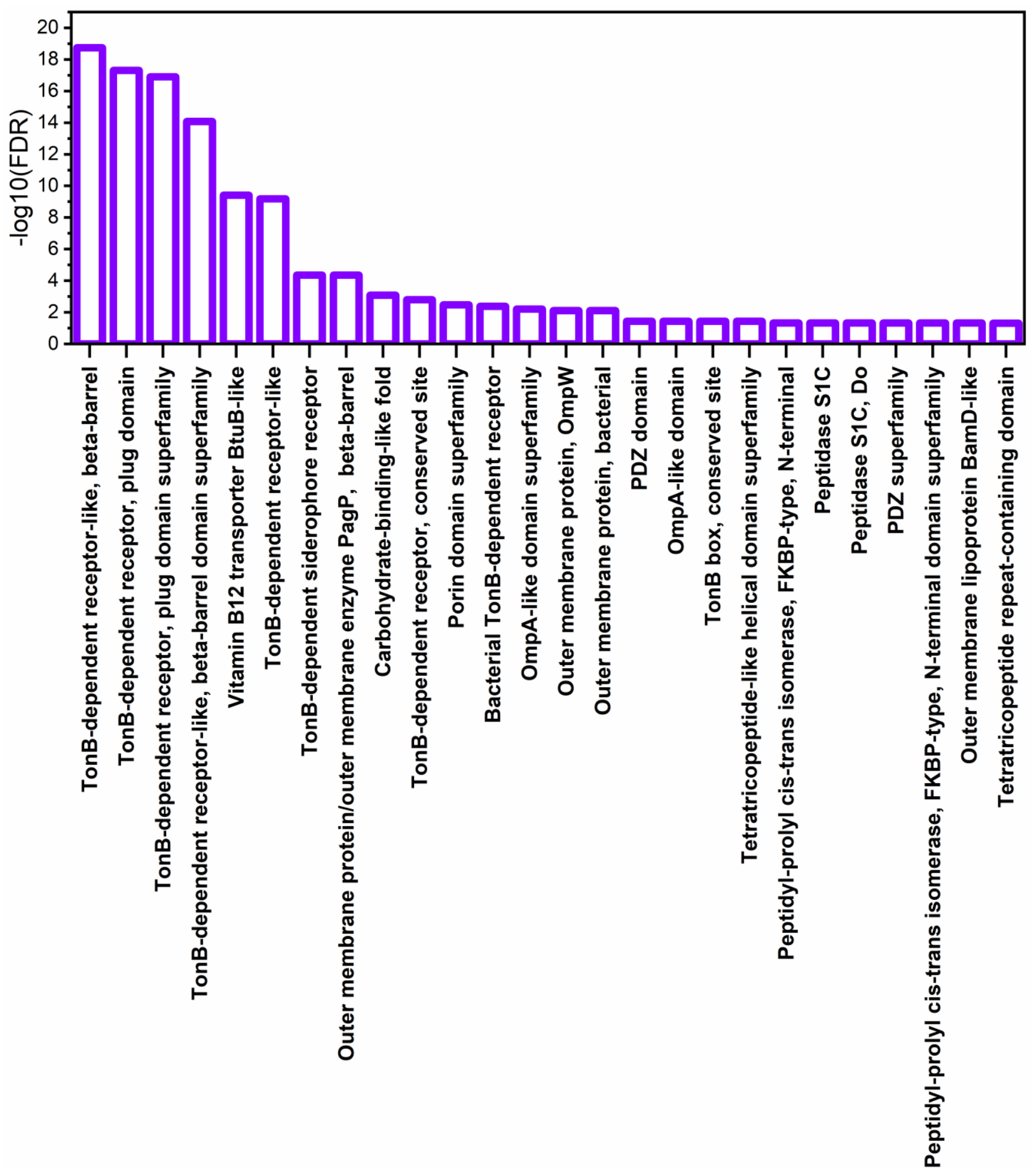

871 Fig. S3. Most significantly enriched InterPro domains found in the purified OMVs

872 compared to the $X$. citri pv. citri 306 genome. The lowest false discovery rates (FDR), thus the

873 highest - $\log 10($ FDR) values, were observed for domains related to TonB-dependent receptors. 